\title{
Towards the Revolution and Democratization of Education: A Framework to Overcome Challenges and Explore Opportunities through Industry 4.0
}

\author{
Ana Carolina Ferreira COSTA, Vitor Homem de Mello SANTOS, \\ Otávio José de OLIVEIRA \\ Department of Production, Sao Paulo State University - UNESP \\ Guaratinguetá, Brazil. \\ e-mail: ana.c.costa@unesp.br,vitor.homem@unesp.br,otaviodeoliveira@uol.com.br
}

Received: February 2021

\begin{abstract}
Education 4.0 (E4) aims to improve the teaching-learning process and democratize access to quality education by using Industry 4.0 technologies in educational environments. The main objective of this article is to propose a framework containing a package of policies and initiatives for the drivers of society (industry, government, and academia) to develop E4. The framework was elaborated through systematic review based on good practices, challenges, and opportunities of E4, which were systematized considering the technical-scientific literature and the authors' experience. The main scientific contribution of this work is the creation of a new block of knowledge about E4 that expands and at the same time deepens the existing literature and can support new research and foster initiatives on the subject. Its main applied contribution is to increase access to quality education through the development of E4.
\end{abstract}

Keywords: Education 4.0, Industry 4.0, Technical-Scientific Scenario, Development Framework, Triple Helix.

\section{Introduction}

Quality and accessible education for all is the fourth Sustainable Development Goal (SDG) of the United Nations (UN) and has been highlighted in international agendas in recent decades. Education is crucial to promote the improvement of social and economic conditions, especially for people living in extreme poverty (UN, 2020). To achieve SDG 4, Information and Communication Technologies (ICT) are important tools that can be used to democratize and expand access to quality education (UNES$\mathrm{CO}, 2017)$. One of the indicators proposed by the UN to measure the performance of this SDG is related to the percentage of people who have the skills to use ICT (UNESCO, 2018). 
The use of ICT has enabled advances of various orders and driven changes in industry toward the era of the Fourth Industrial Revolution or Industry 4.0 (I4). I4 is characterized by the evolution in the interaction among electronic devices, machines, and people. It integrates the technologies developed to support real-time decision-making through Cyber-Physical Systems (CPS), Internet of Things (IoT), Cloud Computing (CC), Big Data (BD), etc. This revolution is transforming the job market and demanding professionals with new skills and competencies (Benešová and Tupa, 2017; Lee et al., 2015; Xu et al., 2018).

For preparing qualified professionals for these demands and provide higher quality education, initiatives to reformulate the teaching models have been proposed using I4 technologies and different pedagogical approaches. These reformulations are originating a real revolution in education, called Education 4.0 (E4) (Almeida and Simoes, 2019; Martín-Gutiérrez et al., 2015; Mian et al., 2020). The E4 uses I4 technologies and collaborative, flexible, and personalized pedagogical approaches to update teaching methods. It brings together elements such as gamification, flipped classroom, among others, to engage and qualify students, increasing the effectiveness of teaching-learning (Ab Rahman et al., 2019; Chang and Hwang, 2018; Popenici and Kerr, 2017).

The integration of technologies into education is considered promising by academia and governments of several countries. However, the results of the Programme for International Student Assessment (PISA) conducted with 15-year-old students in 2018 in 79 countries indicated a lack of infrastructure, support, and quality Internet access at participating educational institutions. In OECD (Organisation for Economic Co-operation and Development) countries, only $65 \%$ of principals believe that their teachers have sufficient skills to integrate ICT into the teaching-learning process. Although most OECD countries are developed, have high-income economies and high Human Development Index, only $50 \%$ of the schools consider they have adequate technical support and online learning platform (OECD, 2020). Therefore, the education scenario in countries not belonging to this organization should probably present much lower results.

Due to intense global demand for increased access to quality education and technological advances, the World Economic Forum (2020) produced the School of the Future report to propose an $\mathrm{E} 4$ model and present some of its successful initiatives. The study by Bonfield et al. (2020) discussed and highlighted the importance of using E4 approaches in the teaching-learning process at universities in the UK, Australia, and Singapore. The study by Mian et al. (2020) identified the challenges and opportunities of I4 teaching at universities and proposed recommendations for developing University 4.0.

However, it is important to conduct more studies that propose solutions to overcome the technological challenges of E4, because of its great potential to democratize and improve education. This work deepens the above-mentioned studies and makes it possible to fill scientific gaps related to the need to integrate I4 technologies with education (Akçayır and Akçayır, 2017; Arpaci, 2017; Huang et al., 2016b) and identification and solution of the main challenges related to this integration (Skryabin et al., 2015; Tashkandi and Al-Jabri, 2015; Yilmaz, 2016). 


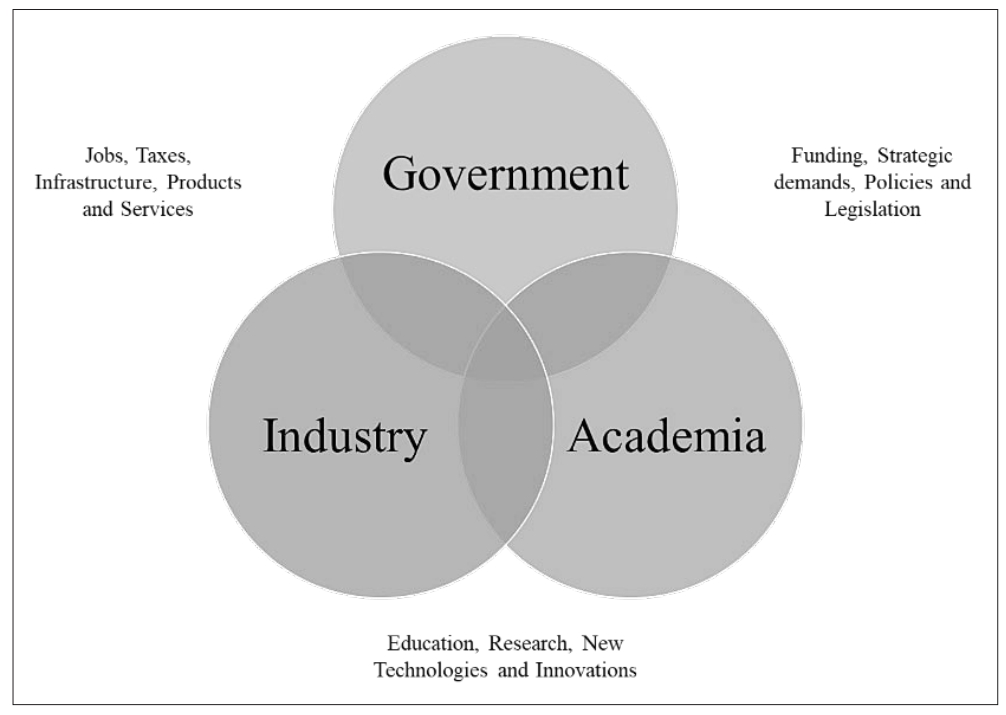

Fig. 1. Triple Helix Model.

Adapted from Kimatu (2015).

Several challenges directly influence the use of ICT in education, such as lack of infrastructure and technological support in the teaching environment, the difficulty of teachers in using them, and deficiency of appropriate educational platforms and software (Gil-Flores et al., 2017; Wei et al., 2015). These challenges are complex and should be addressed collaboratively by the main actors in society (industry, government, and academia) represented by Triple Helix and illustrated in Fig. 1 (Daniel, 2015; Ghavifekr and Rosdy, 2015; Kimatu, 2015).

The Triple Helix model proposes a continuous interaction among agents that compose it to accompany the evolution of technologies and respond to society's global challenges (Galan-Muros and Davey, 2019). The results of these interactions are derived from factors that influence how individuals use and interact with technologies in practice, leading to the emergence of new structures and advanced technologies (Orlikowski, 2000). To support all transformations, policies and innovations must be frequently proposed to society's actors (Hussenot, 2008). In this way, the Triple Helix agents proactively contribute to socioeconomic development through the creation of policies and partnerships, training of professionals, research and development (R\&D), innovations, and technological infrastructure (Gachie, 2020; Razorenov and Vodenko, 2020).

The agent industry is responsible for providing innovative products and services for the education area and increasingly demands better qualified professionals in I4 technologies, which can be developed through E4 (Benešová and Tupa, 2017; Kimatu, 2015). The government, for its part, must create and propose policies that regulate the interactions of sectors of society, encouraging and financing the improvement of teaching methods, increasing the level of schooling of its population, and improving teachers' formation (Lim et al., 2020b). Academia is responsible for education its students to deal with the 
new technological demands of I4 and develop products and innovations from scientific research to overcome the challenges of I4 in society and industry (Mian et al., 2020).

In this context, the research question that guided the development of this work arises: in what way is it possible to improve the teaching-learning relationship and increase access to education through the technologies of Industry 4.0? To answer this question, this article proposes a framework containing a package of policies and initiatives that can be adopted by industry, governments, and academia for the development of E4, in order to improve the teaching-learning process at all levels of education and democratize access to quality education.

The results of this work contribute scientifically to the creation of a new block of knowledge that deepens and expands the existing literature on E4, creating new bases for future work on the theme. The major applied contribution of this work is to enable the increased access to quality education through the proposal of policies and initiatives that enable E4 development by the principal agents of society.

After this introductory section, this paper is organized as follows: Section 2 provides the literature review; Section 3 describes the research method used in the development of this work and its stages; Section 4 presents the technical-scientific scenario; Section 5 identifies the challenges and opportunities of E4 development; Section 6 proposes E4 development framework; Section 7 offers the conclusion, and finally, the references and appendix are presented.

\section{Literature Review}

Industrial revolutions were movements in which different production methods and processes were inserted into organizations, increasing their competitiveness and improving their productivity. By 2020, four industrial revolutions had emerged in history. The first one contemplated the beginning of manufacturing and the use of steam machines to replace handicraft activity. The second represented mass manufacturing, using assembly lines and electric power. The third characterized the advance of electronics, which made possible the automation of industrial processes and the use of robots (Ghobakhloo, 2018; Pereira and Romero, 2017; Rojko, 2017).

Unlike the first three industrial revolutions, I4 emerged from a strategic plan by the German government in partnership with academia and industry to make its industrial organizations more autonomous, flexible, and collaborative. The goal of I4 is to increase competitiveness by meeting the variations in market demand and to reduce environmental impact. To achieve this, information is made available in real-time to improve decision-making through the implementation of various technologies such as IoT, BD, CC, AI, etc. However, I4 presents several challenges to be implemented and consolidated (Dalenogare et al., 2018; Hofmann and Rüsch, 2017; Wang et al., 2016).

One of the main challenges is related to the demand for professionals with new technical and socioemotional skills such as digital, interpersonal, technology, and innovation skills (Benešová and Tupa, 2017; Pereira and Romero, 2017; WEF, 2020). To overcome this challenge, education has a fundamental role to train better qualified professionals 


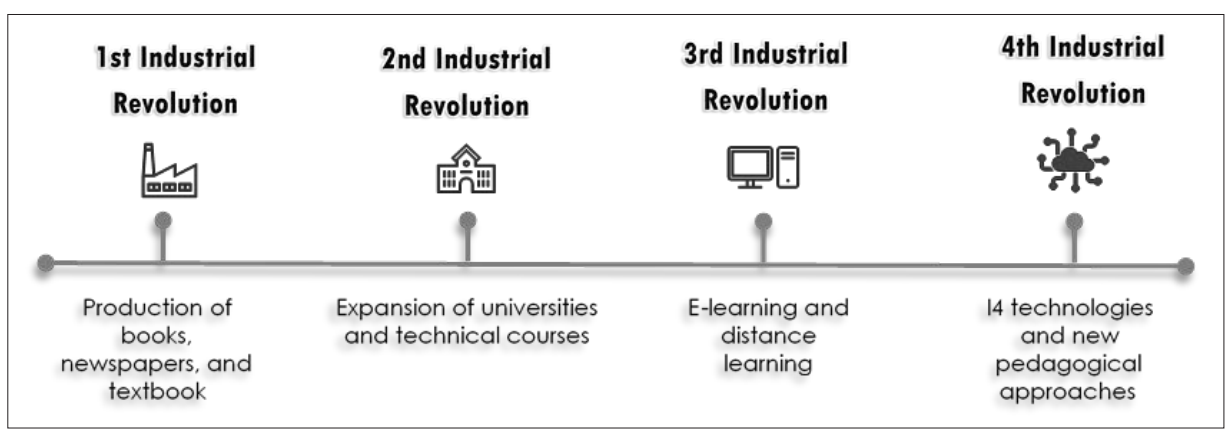

Fig. 2. Industrial revolutions and education.

Based on Bonfield et al. (2020), Li (2020), Yusuf et al. (2020).

and provide improvements in people's quality of life (Alvarenga et al., 2021). In this sense, E4 is being proposed to support I4 and social change through the integration of technologies in the teaching-learning process and the use of new pedagogical approaches (Hariharasudan and Kot, 2018).

E4 is the result of the evolution of educational systems aimed at supporting socioeconomic development (Koul and Nayar, 2021). This interaction between education and industry is recurrent and has happened throughout the other industrial revolutions, as illustrated in Fig. 2. In the first revolution, knowledge was expanded and disseminated through new universities, books, and newspapers. In the second revolution, education mainly contributed by training engineers and technicians for industry and increasing the supply of higher education courses ( $\mathrm{Li}, 2020)$. The invention of computers and the emergence of the Internet during the third industrial revolution enabled the creation of e-learning and the popularization of distance learning courses (Yusuf et al., 2020). The fourth revolution enables the use of technologies such as $\mathrm{AI}, \mathrm{BD}$, and $\mathrm{CC}$ in teaching environments to enhance the teaching-learning process and support I4 (Bonfield et al., 2020).

Therefore, the proposed new model of education called E4 comprehends two complementary areas. The first one aims to develop students' skills and competences, training them according to the needs of the factories that use I4 technologies, and to this, has used new teaching approaches. The second aims at the insertion of I4 technologies in educational environments as a tool for improving the teaching-learning process (Bonfield et al., 2020; Hariharasudan and Kot, 2018; Reis et al., 2020). Several I4 technologies can be used in teaching environments to motivate students and support teachers. Among them are AR, VR, CC, BD e AI (Huang et al., 2016b; Shiau and Chau, 2016; Wei et al., 2015).

AR enables animated virtual objects to be viewed in the real environment through tablets or smartphones. This technology allows the improvement of the teaching-learning process and increased collaboration and motivation of students. It can be used to simulations of practical activities in various areas such as physics, engineering, and architecture (Akçayır and Akçayır, 2017; Batista et al., 2020; Huang et al., 2016b).

VR provides the immersion of students in a virtual environment for teaching more interactively. It can be used to simulate experimental practices that are difficult to repli- 
cate due to security and cost issues. This technology can be applied at all levels of education, such as the training of doctors, pilots, and teaching science to children. However, VR needs the development of more software to expand and facilitate its use by teachers and students (Alhalabi, 2016; Jensen and Konradsen, 2018; Takala et al., 2016).

$\mathrm{CC}$ is becoming increasingly used in teaching platforms for providing networked file storage and management services. This technology allows users to simply access its content anytime and anywhere. Examples of cloud applications are Google Apps, Dropbox, and OneDrive. CC brings ease of use and access to documents, increase in collaboration among students, and reduction in hardware costs and IT support. Its main challenge is the security of data sharing and the need for a high-speed Internet connection for its operation (González-Martínez et al., 2015; Sabi et al., 2016; Shiau and Chau, 2016).

$\mathrm{BD}$ is one of the $\mathrm{I} 4$ technologies that allow the analysis of large amounts of data in various areas of society. In education, BD can be used to analyze standards in academic performance throughout the school term and discover students at risk of failure and enable teachers to conduct personalized actions in teaching for these students. However, the application of this tool has a high implementation cost and can become complex when the data are decentralized and in different formats (Almohammadi et al., 2017; Daniel, 2015; Huda et al., 2017).

AI is an I4 technology widely applied to analyze data and perform the decisionmaking process. In teaching, this solution complements the role of teachers and assists students in the teaching-learning process. The AI allows teachers to customize the content for each student from the analysis of their strengths and weaknesses. This technology also enables students' questions to be quickly resolved through intelligent virtual assistants in educational environments (Almohammadi et al., 2017; Popenici and Kerr, 2017; Terzopoulos and Satratzemi, 2020).

These I4 technologies have been increasingly used in education at all levels (elementary, upper, secondary, and postsecondary). However, for native digital students, that is who was born in a connected and digital society, it is greater acceptance of these innovations. When this type of student is immersed in an environment with technologies, the engagement with the content taught is better and their performance improves. Even for students who are not digital natives, the use of technologies in the classroom is relevant to improve the teaching-learning process, making it more interactive and attractive (Ghavifekr and Rosdy, 2015; Huang et al., 2016a).

Teachers play a key role in driving the transformation of education and encouraging the use of technologies in the teaching-learning process. Therefore, their digital skills and competencies must be developed through teacher education programs, training, and public policies (Burns and Gottschalk, 2020). Several frameworks are mapping and bringing together the skills that should be developed in teachers, such as DigCompEdu. DigComEdu covers 22 competencies divided into 6 main areas that teachers should possess to implement ICT in teaching (Lucas et al., 2021). These are professional engagement, digital resources, teaching and learning, assessment, empowering learners, facilitating learners' digital competence. The goal of this framework is to enable teachers to be able to select and apply technologies in teaching environments, engaging students through personalized and inclusive learning (Redecker, 2017). 


\section{Research Method}

This work was developed from a systematic review of technical-scientific literature on Education 4.0. The systematic literature review is a research method based on the critical analysis of literature that allows the identification of the most relevant and recent studies and initiatives on the subject. The literature review must comprise several sources of data to be relevant and effective (Cronin et al., 2008). In this study, content analyses of the main technical and academic publications on E4 were conducted. Among the publications analyzed, there are industrial initiatives, patents, law texts, policies, business and government reports, and scientific articles.

Thus, the technical-scientific scenario was mapped in the E4 area composed of the policies, initiatives, and innovations of the 4 countries that highlighted both in the development of technologies and the publication of articles on E4. The technicalscientific scenario served as a benchmark for the authors of the study, who compiled, analyzed, and adapted the good practices in the teaching environments of these countries considering their experiences and the literature to propose an E4 development framework. The study was conducted according to the flow of activities presented in Fig. 3.

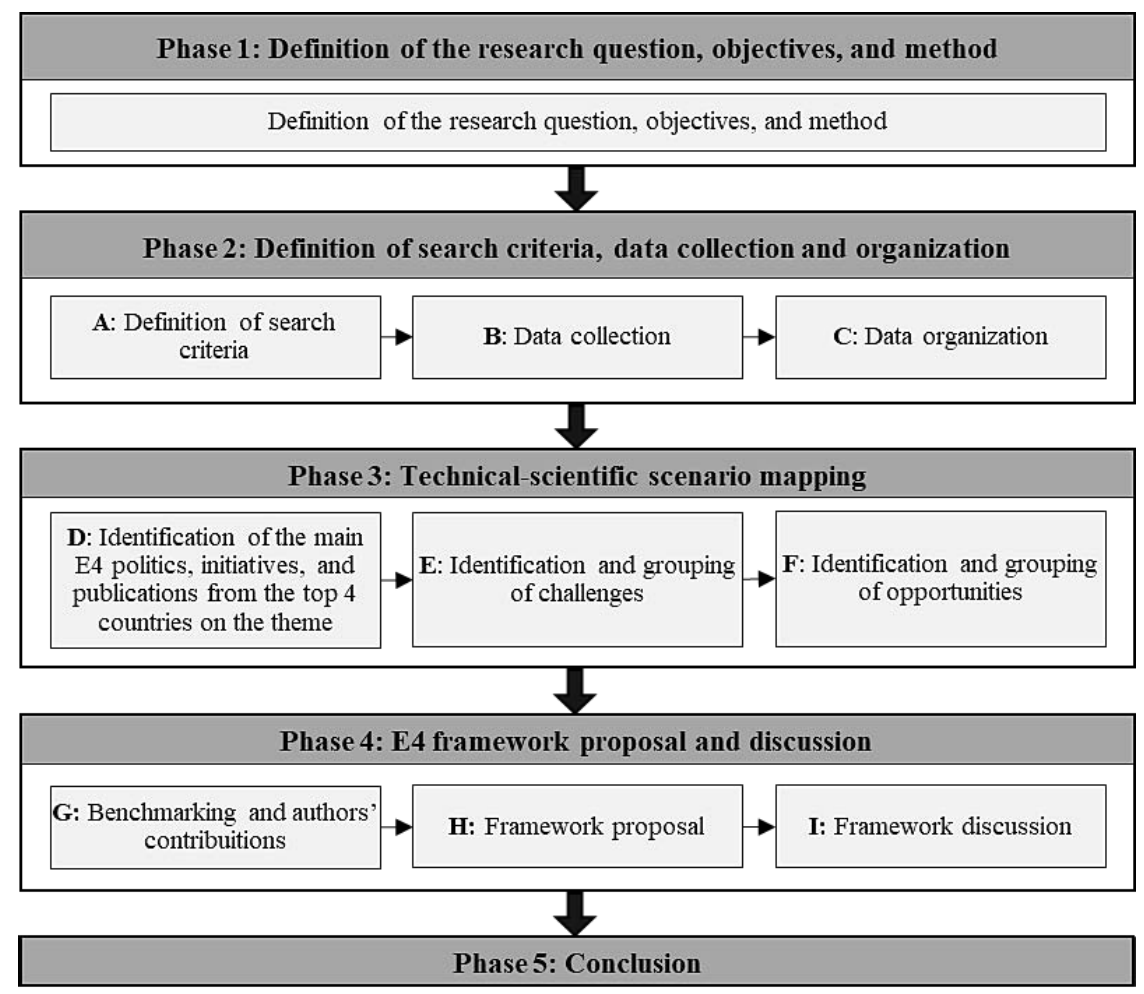

Fig. 3. Research activity flow. 
The work was divided into five phases: definition of the research question, objectives, and method; definition of search criteria, data collection and organization; technical-scientific scenario mapping; E4 framework proposal and discussion; and conclusion. Table 1 details each of these phases and their stages.

Table 1

Research phases and stages

\begin{tabular}{ll}
\hline Phases & Stages \\
\hline $\begin{array}{l}\text { Phase 1: } \\
\text { Definition of } \\
\text { the research }\end{array}$ & $\begin{array}{l}\text { Definition of } \\
\text { the research } \\
\text { question, ob- }\end{array}$ \\
$\begin{array}{l}\text { question, ob- } \\
\text { jectives, and } \\
\text { method }\end{array}$ & $\begin{array}{l}\text { method, and } \\
\text { Phase 2: }\end{array}$ \\
$\begin{array}{l}\text { Definition } \\
\text { of search } \\
\text { criteria, data } \\
\text { collection, } \\
\text { and }\end{array}$ & $\begin{array}{l}\text { Definition } \\
\text { of search } \\
\text { crganization }\end{array}$ \\
\end{tabular}

The criteria for technical and scientific data search were defined. The Orbit Intelligence platform was chosen for the search of technical data and analysis of patents since it encompasses the largest patent repositories filed by companies and universities around the world (Vincent et al., 2017). The patents studied must have been registered between 2010 and 2020 to represent the trends and innovations of the theme.

The Scopus database was chosen to search for the scientific data. It is one of the most comprehensive scientific databases and allows access to papers published on the subject around the world. The articles studied were published in the last five years (2015-2020) in the English language, which is the most used in the scientific environment (Mongeon and Paul-Hus, 2016; Reis et al., 2017). This period was chosen because the studies published in the last five years consolidate and expand previous works in the literature and represent real and current practices on the subject.

Two sets of keywords were used in the search, as explained in the following figure. The first set was composed of the word "Education 4.0" and its synonyms ("Learning 4.0", "Teaching 4.0", and "Educational 4.0"). The second set was composed of words related to I4 and its technologies ("Industry 4.0", "ICT", "Big Data" etc.) combined with words related to teaching ("Education", "Teaching", "Educational" etc.). Articles must contain words from the first set or the second in their titles. Thus, it was possible to include studies on the use of I4 technologies to improve the teaching-learning process, which characterizes E4.

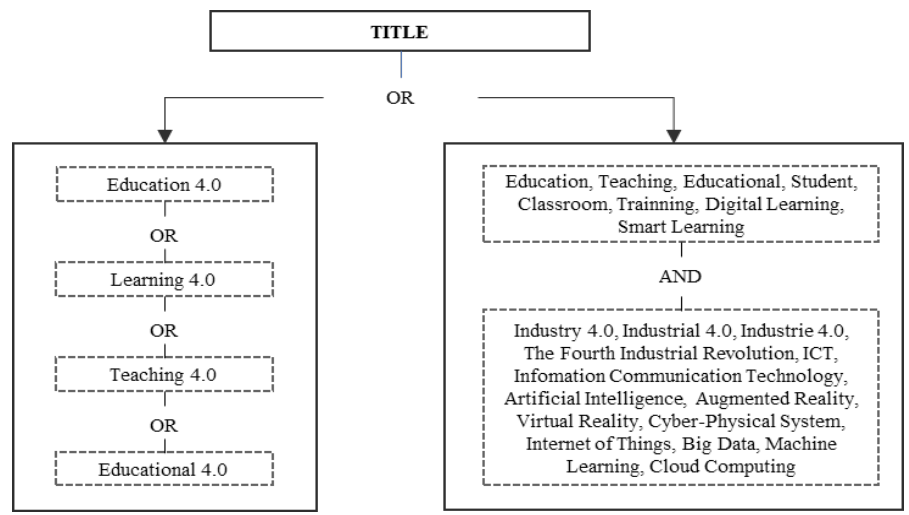


Table 1 - continued from previous page

\begin{tabular}{|c|c|c|}
\hline Phases & Stages & Description \\
\hline & $\begin{array}{l}\text { B: } \\
\text { Data } \\
\text { collection }\end{array}$ & $\begin{array}{l}\text { Information from } 4273 \text { patents and } 1973 \text { scientific papers that met the search } \\
\text { criteria was collected. Among these articles, the } 30 \text { most cited were selected for } \\
\text { the analysis of their contents and identification of the challenges and opportunities } \\
\text { for E } 4 \text { development. } \\
\text { The } 30 \text { articles most cited are presented in Appendix A. }\end{array}$ \\
\hline & $\begin{array}{l}\text { C: } \\
\text { Data } \\
\text { organization }\end{array}$ & $\begin{array}{l}\text { The data collected were organized and the main countries in the E4 technical- } \\
\text { scientific scenario were selected based on the relationship between the two } \\
\text { criteria: h-index and number of registered patents. } \\
\text { At first, the } 10 \text { countries with the highest number of registered patents were } \\
\text { selected and ranked, indicating for the technical scenario of the subject, those } \\
\text { with important R\&D teams of technologies and innovations on E4. } \\
\text { Then, the } 10 \text { countries with the highest h-index in the subject studied were } \\
\text { ranked from the data collected in step B. This index quantifies the productivity } \\
\text { and relevance of published studies and is, therefore, a good indicator of scientific } \\
\text { production capacity (number of publications) and importance (citations) of works } \\
\text { published in these countries (Hirsch, } 2005 \text { ). } \\
\text { Thus, the averages of the positions of the countries that were present in both } \\
\text { rankings were calculated. The countries were arranged in ascending order } \\
\text { according to the calculated average. So, the final ranking of the prominent } \\
\text { countries includes both the technical and scientific scenarios. The first four } \\
\text { countries in this ranking (United States, China, Taiwan, and South Korea) } \\
\text { together cover more than } 80 \% \text { of the number of patents returned from the search, } \\
\text { indicating significant innovations on the subject. For this reason, they were } \\
\text { selected for the qualitative analysis of their main industrial, governmental, and } \\
\text { academic initiatives. } \\
\text { Then, the three companies that registered the most patents on E4 and the three } \\
\text { authors and universities with the highest h-index in the theme of each country } \\
\text { were selected to be analyzed in the next stage. }\end{array}$ \\
\hline
\end{tabular}

Phase 3: D:

Technicalscientific scenario mapping
D: $\quad$ The main policies and initiatives in E4 of companies, governments, and academia Identification belonging to the countries identified in step C were mapped, to support the work of the main and provide a benchmark to the authors.

E4 politics, In each country, the analysis of the main initiatives of the three companies that initiatives, and articles from the top 4 countries on the theme have registered most patents on the subject was conducted. Their initiatives were identified through the analysis of the content of their business reports, patent texts, and official websites.

Then, the relevant government policies in the E4 area were identified in the four outstanding countries in the technical-scientific scenario. They were mapped from the analysis of texts of laws, official websites, and scientific articles dealing with the theme.

Finally, the initiatives and articles of the authors and universities highlighted in the theme selected in step C were systematically analyzed to identify their objectives, methods, and main contributions to the development of E4.

E: $\quad$ Content analysis was conducted on the 30 most cited and selected articles in step Identification B of this work. The objectives, methods, contributions, and challenges for the E4 and systema- development of each study were identified and systematized from its analysis. tization of challenges F: Identification and systematization of opportunities They were then grouped according to their similarities and discussed.

The same procedure of step E was conducted but focused on identifying the scientific opportunities for E4 development. After that, these clusters were discussed. 
Table 1 - continued from previous page

\begin{tabular}{|c|c|c|}
\hline Phases & Stages & Description \\
\hline \multirow[t]{3}{*}{$\begin{array}{l}\text { Phase 4: } \\
\text { E4 } \\
\text { framework } \\
\text { proposal and } \\
\text { discussion }\end{array}$} & $\begin{array}{l}\text { G: } \\
\text { Benchmark- } \\
\text { ing and } \\
\text { authors' } \\
\text { contributions }\end{array}$ & $\begin{array}{l}\text { The policies and initiatives mapped in the technical-scientific scenario and the } \\
\text { challenges and opportunities to E4 development were analyzed by considering } \\
\text { the literature and experience of the authors of this study. Policies and initiatives } \\
\text { were expanded and adapted to the areas of Triple Helix sectors through } \\
\text { a benchmarking process of the good practices identified in the E4 scenario. } \\
\text { The policies implemented by the countries studied to modernize their education } \\
\text { systems were appropriate to the industrial and academic sectors as suggestions } \\
\text { for practices for the development of E4. The scientific and technical advances } \\
\text { developed at universities, researchers, and companies were used as a benchmark } \\
\text { to propose broader initiatives and research topics to promote the use of I4 } \\
\text { technologies in teaching and overcome the challenges of E4. }\end{array}$ \\
\hline & $\begin{array}{l}\text { H: } \\
\text { Framework } \\
\text { proposal }\end{array}$ & $\begin{array}{l}\text { The elements of the framework were proposed considering the analysis performed } \\
\text { in step G of this work. The framework was elaborated with proposals for policies } \\
\text { and initiatives that can be adopted by industry, governments, and academia to } \\
\text { develop E4, to improve the teaching-learning process at all levels of education } \\
\text { and democratize access to quality education. }\end{array}$ \\
\hline & $\begin{array}{l}\text { I: } \\
\text { Framework } \\
\text { discussion }\end{array}$ & $\begin{array}{l}\text { The policies and initiatives of the framework were discussed in the light of } \\
\text { the literature to provide scientific robustness to the results and allow a full } \\
\text { understanding of the proposal. }\end{array}$ \\
\hline $\begin{array}{l}\text { Phase 5: } \\
\text { Conclusion }\end{array}$ & Conclusion & $\begin{array}{l}\text { The fulfillment of the objectives proposed in this work and the main scientific } \\
\text { and applied contributions of its results were highlighted, besides its limitations } \\
\text { and suggestions for future works. }\end{array}$ \\
\hline
\end{tabular}

Thus, the research phases and steps described in Table 1 allowed the mapping of the most relevant policies and initiatives of the main institutions of the E4 technicalscientific scenario and the identification of the main scientific challenges and opportunities of the theme. As shown in Fig. 4, the analysis of the technical-scientific scenario and the authors' contributions of this research assist the proposal E4 development framework.

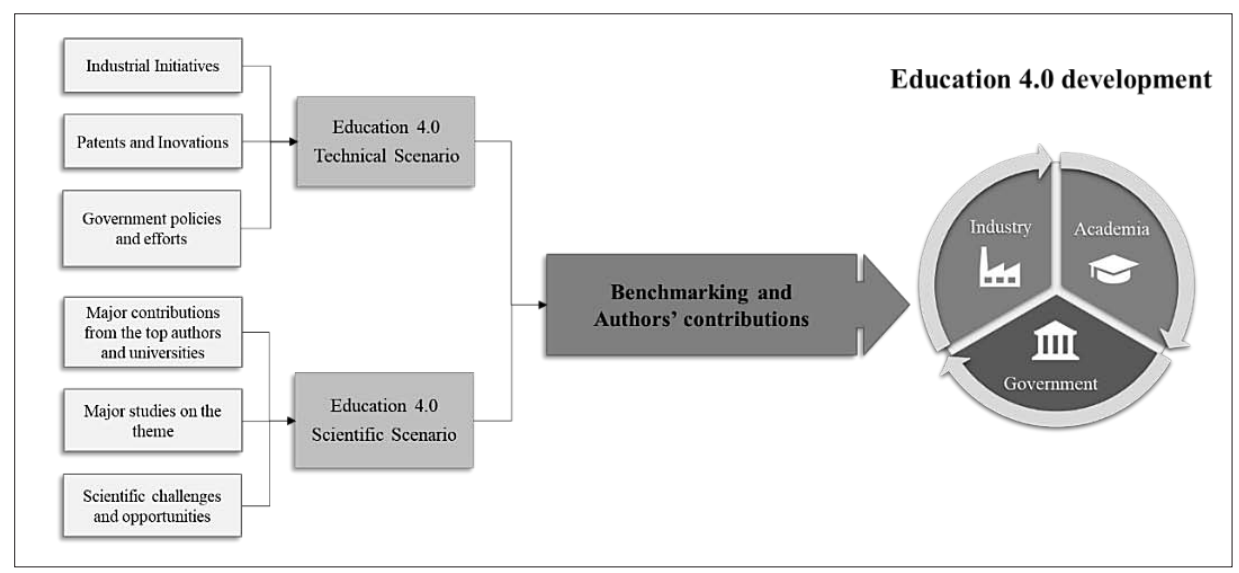

Fig. 4. E4 development framework. 
Table 2

Top Countries in Education 4.0

\begin{tabular}{llrl}
\hline $\mathrm{N}$ & Country & Patents & $\mathrm{H}-$ Index \\
\hline 1 & United States & 260 & 22 \\
2 & China & 3360 & 12 \\
3 & Taiwan & 18 & 15 \\
4 & South Korea & 493 & 9 \\
\hline
\end{tabular}

\section{Technical-Scientific Scenario}

The countries that are contributing to the development of E4 were selected for the elaboration of the technical-scientific scenario. They have the highest h-index and are the ones that have filed the most patents on the subject from 2015 to 2020 according to Scopus and Orbit Intelligence bases, respectively. The countries selected were the United States, China, Taiwan, and South Korea, as shown in Table 2. Their main industrial, governmental, and academic initiatives will be analyzed and presented in the next topics.

\subsection{United States}

The United States is the third country regarding the number of patents filed (260) and has the largest h-index on the subject (22). The American government has been investing in the development and application of new teaching practices and tools in its educational system since the 1990s. Therefore, the country is at the forefront of E4 and is house to leading companies and universities in the development of technologies and research in the area.

\subsubsection{Industry}

The companies that have the most patents published in the US are Samsung Electronics (47), Lincoln Electric Global (24), and IBM (8). They are recognized for developing I4 technologies for education and for using them in their training and qualification.

Samsung develops educational technologies such as mobile devices, e-learning platforms, digital flipchart, and projects in partnership with schools and universities to support and enhance digital learning (Samsung, 2013). In one of its successful partnerships with the College of Business at Colorado State University (CSU), Samsung has created a television structure to reinvent distance learning so that remote students can be viewed and interact with students and teachers in real-time. In this way, the project increases the engagement and collaboration among students to improve learning and expand the ability of educational institutions to train new professionals for the job market (CSU, 2019; Haynes, 2019).

Lincoln Electric Global is a company that manufactures welding products and offers training to companies and new welders at its education institute (Lincoln, 2017). 
Among the products and services marketed by the company are the robotic training and simulation tool with VR. The simulation technology allows a mobile and safe teaching environment for welding practice. The tool provides a real-time report with feedback activity analysis data, supporting teachers and students in the teaching-learning process (Lincoln Electric, 2018).

IBM is an information technology company that develops and markets products and services such as CC, AI, and Machine Learning. The company created P-TECH in partnership with academia and other industries to provide free teaching and internship in the areas of STEM (Science, Technology, Engineering, and Mathematics) for needy people (IBM, 2020). P-TECH also has an online teaching platform with free courses and certifications for developing of technical skills and technologies such as Blockchain, Data Science, and AI (P-TECH, 2020).

\subsubsection{Government}

In the governmental sphere, the Every Student Succeeds Act aims to ensure that every graduate student has access to digital learning and this end, allocates financial resources to projects that promote and implement blended learning and digital learning (U.S. Department of Education, 2019). The Nation Science Foundation (NSF) is also an important source of research funding for developing of educational technologies (NSF, 2020a). NSF funds science and engineering projects such as "Smart Advanced Manufacturing Education in the Silicon Valley", which proposes to develop a program with new courses to meet the demands of well-qualified I4 professionals, focusing on areas such as the Internet of Things, Prototyping, and Automation (NSF, 2020b).

\subsubsection{Academia}

The main academic initiatives in the country were analyzed based on the most prominent authors and universities on the subject. David F. Cihak, Don D. McMahon, Nassir Navab, Timothy Green, and Abbie Brown have used and innovatively study emerging technologies in teaching in their articles.

The authors David F. Cihak and Don D. McMahon have contributed with studies to improve teaching with emerging technologies such as mobile devices, AR, and VR in schools and training courses for people with disabilities (University of Tennessee, 2012; Washington State University, 2020). These technologies are used to teach science, encourage the practice of physical exercise and support the development of professional skills of students to enter the job market (Washington State University, 2016). Nassir Navab and his research team called Computer Assisted Medical Procedures (CAMP) use AR, VR, robotics, and machine learning combined with medicine, engineering, and medical solution providers to develop mechanisms for teaching anatomy and assisting physicians in surgery more accurately (CAMP, 2014). Tim Green and Abbie Brown contributed by identifying the best mobile device software that can be used to implement AR in classrooms. Among them, Aurasma software is distinguished for its functionality and was applied in the teaching of history and geography in basic education to increase student engagement in the teaching-learning process (Green et al., 2017). 
The American universities University of Illinois at Urbana-Champaign (UIUC), University of Arizona (UA), and NC State University (NCSU) have excelled in publishing studies on E4 and in applying and developing innovative teaching techniques and tools.

UIUC has developed studies on the application of BD, data science, and machine learning techniques in the evaluation of learning in digital teaching environments and the prediction of student behavior (Cope and Kalantzis, 2015; Paquette and Baker, 2019). Such techniques allow the analysis of the results of new technologies quickly, accurately, and safely. At UIUC, studies on the responsible use of BD in Art teaching were also developed (Duncum, 2018), and the use of VR and simulation in archaeology teaching (Shackelford et al., 2019). The use of VR has favored the students' cognitive learning by allowing interaction with the study environment, which has made teaching more dynamic and practical.

The UA has developed studies on the use of VR and BD in the teaching of medicine and foreign languages (Iserson, 2018). VR has proven to be an important ally in teaching and learning skull-based lateral surgeries and clinical testing procedures by simulating 3D environments where students could practice these activities (Barber et al., 2020). Studies were also conducted on the application of artificial intelligence in teaching Braille to the visually impaired, where students improved their learning performance (McCarthy et al., 2016); and the application of new ICT in teaching reading and spelling (Schneider et al., 2015).

NCSU studied the application of AR in teaching topography, engineering, and veterinary medicine. The use of this technology helped students in the three-dimensional understanding of topics such as topographic mapping studies and dog neuroanatomy, proving the multidisciplinary potential of its application. This technology has considtheerably increased student engagement and performance (Akbulut et al., 2018; Christ et al., 2018; McNeal et al., 2020; Soltis et al., 2020). NCSU studies also identified that VR, mobile learning, interactive learning environments, and e-learning technologies are the most widely used in the area of AR for education (Karakus et al., 2019).

\subsection{China}

China is the country with the highest number of registered patents (3360) and is the third country in the h-index classification (12) on the subject. The country has been recognized for developing technologies and patents, its policies to modernize teaching, and the publication of important scientific studies in E4.

\subsubsection{Industry}

The main technical initiatives of the country were analyzed according to the companies that most deposited patents on the theme in the period studied. They are Shangai Yixue Education (18), Gansu Pugongying (18), and State Grid Corporation (16).

Shangai Yixue Education is the first company to specialize in adaptive learning with AI in China (Squirrel AI Learning, 2017). The company provides personalized educa- 
tion, blending face-to-face and online teaching with I4 emerging technologies. Its AI system simulates teachers and provides a personalized teaching plan based on an intelligent algorithm for capturing and mining students' learning data in real-time and accurately identify their difficulties, setting their priorities in underperformance subject (Squirrel AI Learning, 2020).

Gansu Pugongying Information Technology is a technology developer company and seeks the improvement of hardware to enable software advances in teaching. Its inventions contribute to increasing the efficiency and useful life of the equipment that uses online teaching technologies with AI (Xuecheng, 2019).

State Grid Corporation of China is an electrical energy transmission and distribution company that develops simulation systems using technologies such as AR, VR, drones, and $3 \mathrm{D}$ software for training of its professionals in high power equipment. Their systems are safe and cost-effective solutions for teaching practices that are difficult to implement and replicate (Shengli et al., 2019; State Grid Corporation, 2017; Yan et al., 2016).

\subsubsection{Government}

To boost education at all its levels, the Chinese government launched the long-term "China Education Modernization 2035" plan and the short-term "Implementation Plan to Accelerate the Promotion of Education Modernization (2018-2022). The Chinese government emphasizes the importance of integrating education systems with information technologies, using tools such as AI, DB, simulations, and AR to improve and innovate in teaching and training new professionals. The government also plans an annual increase in the budget for funding projects to modernize education and promote research exchanges abroad, encouraging international collaboration among universities to create research centers in I4 technologies and intelligent campuses (Australian Government, 2020; Shuo, 2019).

\subsubsection{Academia}

The main academic initiatives in the country were analyzed based on authors and universities of prominence in the subject. The authors Cher Ping Lim, Di Wu, and Danhui Zhang have studied the use of ICT and their benefits for the teaching-learning process.

Cher Ping Lim has investigated and analyzed the use of virtual games and ICT to improve the teaching and training of new teachers. Its research uses case studies in universities and schools in Asian countries that have integrated ICT into teaching to identify challenges and propose innovative strategies for curricular upgrades (Lim et al., 2015, 2020a). Di Wu has researched to investigate the effects of integrating ICT, online platforms, and $\mathrm{CC}$ into education and assess the benefits and challenges of their application in rural and urban areas (Shi et al., 2014; Wu et al., 2019a).

Danhui Zhang verified a positive relationship between the use of ICT in teaching and student performance in subjects such as mathematics, science, and reading upon studying the results of international exams such as PISA and PIRLS (Progress in International Reading Literacy Study) (Skryabin et al., 2015; Zhang and Liu, 2016). 
Chinese universities Beijing Normal University (BNU), East China Normal University (ECNU), and University of Science and Technology Liaoning (USTL) highlighted as the most published studies on Education 4.0. Their main contributions in the area are described in the following.

BNU has conducted studies on the impact of ICT use in teaching reading, mathematics, and science in China. The university studied the use of VR in the education of students with autism (Hu and Han, 2019) and in teaching problem-solving skills to elementary school students (Wu et al., 2019b). This technology enables greater immersion and interaction in the learning process, proving useful in special education. BNU studies have also identified an increase in student learning gains from the use of AR technologies in teaching abstract concepts of statistics, probability, and mathematics (Cai et al., 2020a, 2020b). The university has also developed an e-learning model based on elastic cloud computing. This technology allows the construction of computer architectures for distance learning with less investment in infrastructure, which facilitates the implementation of these initiatives (Zhang and Zhu, 2017).

ECNU studies on the application of VR in face-to-face learning environments have identified an increase in the sense of students' presence and the relevance of visual processing in children's learning, revealing the importance of the use of new virtual technologies in curricula and teaching materials for these students (Huang et al., 2020; Liu et al., 2020). As a way to better instruct pedagogy graduates on these technologies, ECNU developed for its pedagogy course the subject "Modern Education Technology," in which the main skills and competencies necessary for the use of ICT in teachinglearning are addressed (Lim et al., 2015).

USTL studied the implementation of flipped classrooms and micro-lecture in VR teaching. These pedagogical approaches allowed teachers to understand the difficulties their students faced during the learning process and what were their different study habits and behaviors. Such findings allowed the adaptation of teachers' teaching styles according to their students' needs, which encouraged engagement during classes and improved learning performance (Ji and Han, 2019). The university conducted studies on the use of VR in teaching graphic design and folk art. This technology stimulated students' enthusiasm, creativity, motivation, and sensitivity during class by simulating painting activities ( $\mathrm{Li}, 2017$ ). The university also applied $\mathrm{CC}$ to dance teaching by offering a multimedia system with videos and images during the classes (Li, 2016).

\subsection{Taiwan and South Korea}

Taiwan has great prominence in the scientific scenario with the third-largest h-index on the subject (15), however, it is the eighth country with the number of patents filed (18). On the other hand, South Korea has great prominence in the technical scenario and is the second country with the highest number of patents filed (493), however, it has a lower prominence in the scientific scenario and is in the tenth position of the ranking according to the h-index in the theme (9). Thus, the initiatives of both countries will be explored together for a better framework proposal. 


\subsubsection{Industry}

The main technical initiatives of the countries were analyzed based on the companies that have filed the most patents. In Taiwan, Dianshi Jingwei Technology (1) and South Korea, Samsung Electronics (88), Total Soft Bank (5) were selected and analyzed.

Dianshi Jingwei Technology has developed a smart and personalized teaching environment based on $\mathrm{AI}, \mathrm{BD}$, and $\mathrm{CC}$ in its line of software and hardware called OKAY Smart Classroom. This environment has scoring reports with the evolution of student learning in subjects and mobile devices that enable learning anytime and anywhere (Okay Smart Education, 2017, 2020).

Samsung Electronics, now analyzing its performance in Korea, created the Smart School program that offers a high-tech teaching system with interactive whiteboards, tablets, laptops, and personalized teaching for needy schools in remote areas intending to reduce the digital education gap (Samsung, 2020b). The company also has programs in other countries like Samsung OneWeek in which its professionals voluntarily dedicate five days of their vacation to teach IT and develop digital skills of students in needy schools and remote communities (Samsung, 2020c). In addition, the Samsung Innovation Campus program aims to develop the skills required by I4, offering training in IoT, BD, $\mathrm{CC}$, and programming for young people from 14 to 18 years old (Samsung, 2020a)

Total Soft Bank is a company of innovative software solutions for port logistics that uses technologies such as AR and VR to create training products for industries and educational institutions. Its products simulate training environments, using VR for crane control operations and teach technical design with 3D parts visualization and AR (Total Soft Bank, 2008, 2018).

\subsubsection{Government}

In the government sphere, the Taiwanese Ministry of Education (MoE) has been conducting constant reforms in education intending to stimulate the creation of advanced digital learning environments and promote the use of e-learning in the country's educational systems (MoE of Taiwan, 2012). The Education Cloud is a platform developed with $\mathrm{CC}$ and $\mathrm{BD}$ by MoE, increasing learning about digital technologies and providing technical resources to teachers and students (Yang and Huang, 2016). MoE created the "Digital Application Promotion Project for Remote Areas" program to develop the use of digital technologies and provide funding to build digital environments in remote areas of the country through the volunteer work of academics and private sector professionals in order to improve the social and economic conditions of the place (MoE of Taiwan, 2020).

The Korea Education and Research Information Service (KERIS) is an institution of the Korean Ministry of Education that aims the development of education with the integration of ICT for improving education due to the demands of I4 (KERIS, 2020a). Its projects use $\mathrm{AI}, \mathrm{DB}$, and $\mathrm{CC}$ to improve elementary school, support the development of educational policies, distance training for teachers, and library digitization (KERIS, 2020b). KERIS also has an e-learning platform intended for higher education, which contains free videos and class materials on various topics, including I4 to encourage knowledge sharing (KOCW, 2015; Lim et al., 2019). 


\subsubsection{Academia}

The main academic initiatives in Taiwan were analyzed based on the authors and universities of prominence in E4. Gwo-Jen Hwang, Ying Shao Hsu, Chin Chung Tsai used learning technologies to improve student performance in elementary and high school subjects.

Gwo-Jen Hwang has research focused on combining AI, mobile learning, AR, and VR with flipped classroom approaches and digital games. He has developed a practical activity with VR for teaching Electromagnetism on a flipped classroom platform to increase the interest and motivation of his students in educational content (Chang and Hwang, 2018; Hwang et al., 2016). Ying Shao Hsu uses AR to develop technological tools and software that promote interest in STEM (Science, Technology, Engineer e Math). In one of his studies, a cardiac surgery simulation tool developed by engineers and doctors of Taiwanese universities was used in the teaching of sciences and it was found an increase in the students' understanding of the importance of the relationship among the areas of STEM (Hsu et al., 2017). Akeem Pedro, C.S. Park, and Q.T. Le have developed VR technologies for teaching construction methods because workers in this industry are often affected by accidents, injuries, and fatalities because of lack of experience and adequate training. These technologies made the learning environment safer and allowed practical experiences in the topic (Le et al., 2015; Pedro et al., 2016; Pham et al., 2018).

The National Taiwan University of Science and Technology (NTUST) and the National Taiwan Normal University (NTNU) of Taiwan and the Ewha Womans University (EWU) of South Korea have been distinguished by conducting important studies on E4.

NTUST studies have identified the great potential in combining AR with building information modeling (BIM) for the teaching and practice of architecture and civil engineering (Diao and Shih, 2019) and the use of this technology in teaching layout design, allowing students to develop building interior design activities interacting with 3D environments (Chang et al., 2020b). The university has also applied VR in teaching childbirth practices to undergraduate nursing students. The research found that the application of this technology reduced students' anxiety during classes and allowed for better practical learning (Chang et al., 2019).

NTNU studied the use of AR in geography classes about climate and in physical education classes in the development of motor skills (Chang et al., 2020a; Hsiao et al., 2016). This technology was also applied in the teaching of elementary school children, where a collaborative 3D environment was developed in which each student could create their own stories and relate to others. The results of this application have shown that increased reality can facilitate the development of children in group work (Hsu, 2019). The university also proposed and applied a pedagogical framework called Learner-Immersed Virtual Interactive Expedition (LIVIE) in the teaching of geography. LIVIE is based on the use of VR simulations that allow students to explore 3D environments of the locations being studied (Jong et al., 2020).

EWU has developed a machine learning prediction system on the evasion of students from South Korean higher education. This technology allows those responsible for educational institutions to act in advance in cases where the student presents a risk 
of abandonment (Chung and Lee, 2019). The university has also conducted studies on the use of AR in teaching creative skills for writing and story-retelling and in STEM educational programs from the inquiry learning model, an active learning approach (Ahn and Choi, 2015, 2016).

\section{Scientific Challenges and Opportunities for E4 Development}

In this topic, the challenges, and scientific opportunities of E4 development are presented and analyzed. The main challenges of E4 correspond to the difficulties and barriers that are hindering its development and implementation in educational institutions in several countries. They have been identified and systematized based on the 30 most cited articles in the scientific literature and grouped into clusters as presented in Table 3.

The first challenge highlights the lack of adequate technological resources for the use of ICT by students and teachers. I4 technologies require the availability of adequate resources and technological infrastructure for their operation. Electronic devices such as computers and tablets need to be in good working order to be used by students and teachers through a quality Internet connection and with technical support available for maintenance and upgrades of hardware and software. In some remote areas and poorer countries, the digital divide is severe, and some educational institutions do not have computers and an Internet connection (Asamoah, 2021; Lim et al., 2020a; Nikolopoulou et al., 2019; Southgate et al., 2019).

The second challenge highlights that in addition to providing adequate technological infrastructure, the success of integrating ICT into teaching depends directly on their acceptance by teachers and principals of the educational institutions. However, many of them have resistance to change and reject the use of technologies in the teaching-learning process, impacting the development and deployment of E4. This may be related to the lack of training that teachers receive during and after their formation. In E4, teachers should have technical and pedagogical skills to use ICT in teaching with autonomy (GilFlores et al., 2017; Hämäläinen et al., 2021; Liesa-Orús et al., 2020).

Table 3

The challenges of E4

\begin{tabular}{|c|c|}
\hline Challenges & Article \\
\hline $\begin{array}{l}\text { Lack of technological infrastructure in good con- } \\
\text { ditions of use and with technical support }\end{array}$ & $\begin{array}{l}\text { Asamoah (2021), Cao et al. (2020), Lim et al. (2020a), } \\
\text { Nikolopoulou et al. (2019), Qasem et al. (2019), } \\
\text { Ghavifekr and Rosdy (2015), Skryabin et al. (2015), } \\
\text { Southgate et al. (2019), Wei et al. (2015) }\end{array}$ \\
\hline $\begin{array}{l}\text { The resistance of teachers and principal in using } \\
\text { I4 technologies in teaching }\end{array}$ & $\begin{array}{l}\text { Hämäläinen et al. (2021), Qasem et al. (2019), Gil-Flores } \\
\text { et al. (2017), Scherer et al. (2015) }\end{array}$ \\
\hline $\begin{array}{l}\text { Absence of legislation and data protection and priva- } \\
\text { cy mechanisms in the use of this information }\end{array}$ & $\begin{array}{l}\text { Fischer et al. (2020), Qasem et al. (2019), Daniel (2015), } \\
\text { González-Martínez et al. (2015), Reyes (2015) }\end{array}$ \\
\hline
\end{tabular}


The third challenge results from the creation and exploitation of data through I4 technologies. There is a great concern with the security of the information shared and especially with privacy in its analysis. Ethical conflicts are under debate to identify who is accessing the data, such as location, tracking, and performance of students and teachers and for what purpose they are used at E4. The technologies used must be secure in order to ensure that the data and information stored on students, teachers, and employees of the educational institutions are not accessed and disclosed by third parties (Fischer et al., 2020; Qasem et al., 2019).

Scientific opportunities are important topics that can be explored for advancing E4 literature and the development of its practices. They have been systematized and then grouped according to their similarities, originating the clusters presented in Table 4.

The first cluster of opportunities identified was about the development of approaches for inserting E4 in teacher training. Teachers are one of the main responsible for the application of new technologies and E4 approaches in the classroom. However, the complexity of some ICT and the lack of digital skills make their use difficult. The main factors that influence the use of E4 technologies by teachers are their skills, knowledge, and perception of the usefulness of these technologies (Gil-Flores et al., 2017; Scherer et al., 2015). Therefore, it is of high relevance that teachers are properly trained and motivated to engage in its use (Valtonen et al., 2015).

The second cluster refers to the need to map the important skills and competences for professionals to work in I4 and introduce them in the curricular grids. The rapid development of new technologies and accelerated globalization, combined with global challenges in the social, economic, and environmental spheres, created a scenario of great uncertainty, that requires students and professionals a new set of skills to face the 21 st-century adversities. Among the current most valued skills are creativity, resil-

Table 4

Clusters of scientific opportunities in E4

Cluster Article

Create approaches for inserting E4 in Benešová and Tupa (2017), Ghavifekr and Rosdy (2015), Gil-Flores teacher training et al. (2017), Gupta et al. (2015), Scherer et al. (2015), Valtonen et al. (2015), Wei et al. (2015)

Map the important skills and com- Benešová and Tupa (2017), Gil-Flores et al. (2017), Gupta et al. petencies for professionals to work in I4 (2015)

and introduce them in the curricula

Propose solutions for integration of Akçayir et al. (2016), Alhalabi (2016), Almohammadi et al. (2017), technology and teaching approaches in Arpaci (2017), Huang et al. (2016a), Huda et al. (2017), Jensen and the E4 Konradsen (2018), Le et al. (2015), Lu and Liu (2015), Sabi et al. (2016), Shiau and Chau (2016), Tashkandi and Al-Jabri (2015), Yilmaz (2016)

Investigate the impacts and challenges Akçayir et al. (2016), Alhalabi (2016), Chang and Hwang (2018), of integrating technologies of the I4 into Daniel (2015), González-Martínez et al. (2015), Huang et al. (2016b), education Hwang et al. (2016) Martín-Gutiérrez et al. (2015) Skryabin et al. (2015), Tashkandi and Al-Jabri (2015), Yilmaz (2016) 
ience, critical thinking, problem-solving, communication, collaboration, and knowledge of technologies. Thus, learning environments should use technologies and teaching approaches that allow students to develop the skills and competencies demanded by modern society. Therefore, they must be identified and inserted in the curricula of schools and universities (Huda et al., 2017; OECD, 2018; Valtonen et al., 2015).

The third cluster emphasizes the need to propose solutions for technologies and teaching methods integrating into E4. Many studies have proven that integrating I4 technologies with education improves student learning and facilitates teaching. ICT, for example, have been used in several countries as a way to make knowledge available to students inside and outside the classroom and to integrate communities of professionals so that they can share good practices in teaching-learning and improve the quality of education (Gil-Flores et al., 2017; Skryabin et al., 2015; Valtonen et al., 2015).

Technologies such as AR and VR allow students to interact with representations of reality in $3 \mathrm{D}$ environments and simulate abstract concepts, facilitating learning and improving students' academic performance (Alhalabi, 2016; Chang and Hwang, 2018; Le et al., 2015; Wei et al., 2015). Therefore, the development of technologies with applicability in different subjects is a great opportunity that can be explored scientifically for developing E4.

The fourth cluster refers to the importance of studies that measure the impacts of the use of E4 technologies in the classroom, helping map the areas with the greatest potential for the application of these technologies and studies that identify the main challenges facing them. Measuring the gains from these applications can guide investments in technologies and support the expansion of their applications to different teaching topics (Hwang et al., 2016; Martín-Gutiérrez et al., 2015; Yilmaz, 2016). Identification of E4's development challenges can drive the search for solutions to facilitate your applications (Akçayir et al., 2016; Tashkandi and Al-Jabri, 2015).

\section{Framework for E4 Development}

In this work, industrial, governmental, and academic initiatives, patents, laws, scientific articles, and challenges and scientific opportunities of E4 were identified and analyzed. This information was used as a benchmark, in other words, compiled, adapted, and expanded considering the experience of the authors to support the proposition of the E4 development framework for Triple Helix agents. The framework is designed for industry, governments, and academia to overcome challenges, explore opportunities, and adopt E4 reference policies and initiatives. Its proposals are segmented into different themes, called domains for each Triple Helix agent, and are summarized in Table 5.

The initiatives proposed in the framework related to the Industry were divided into domains Training and Technology. In Training, the realization of partnerships among companies, universities, and schools is proposed to qualify students according to the skills required by 14 from the modernization of curricula and internships, helping the development of future professionals. Training in companies can be offered through online 
Table 5

E4 development framework

Agents

Government

Education

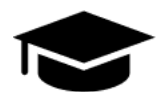

Academia

Economy
Education

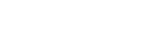

\begin{tabular}{|c|c|c|}
\hline & Use E4 in educational approaches to teach STEM areas & $\begin{array}{l}\text { Government and } \\
\text { Academia }\end{array}$ \\
\hline & $\begin{array}{l}\text { Include and to offer blended learning in their courses and } \\
\text { programs }\end{array}$ & Academia \\
\hline \multirow[t]{3}{*}{ Research } & $\begin{array}{l}\text { Investigate the impacts and challenges of integrating I4 } \\
\text { technologies into education }\end{array}$ & Academia \\
\hline & $\begin{array}{l}\text { Propose solutions for integration of I4 technologies to } \\
\text { teaching }\end{array}$ & $\begin{array}{l}\text { Industry, Government } \\
\text { and Academia }\end{array}$ \\
\hline & $\begin{array}{l}\text { Map the skills and competencies needed for professionals } \\
\text { to work in I4 and introduce them in the curricula }\end{array}$ & $\begin{array}{l}\text { Industry, Government } \\
\text { and Academia }\end{array}$ \\
\hline
\end{tabular}
schools, universities, and the job market and Academia

Government and

Academia

Include and to offer blended learning in their courses and Academia

Investigate the impacts and challenges of integrating I4 Academia

technologies into education

teaching

and Academia

\section{Triple Helix}

Integration
Create online-training platforms for internal and outsourced Industry and employees
Academia
Use E4 tools in training for activities that provide risks Industry and to worker safety or that are difficult to implement and Academia replicate

Partner with universities and schools to modernize curricula Industry, Government and conduct internships to develop the skills required by I4 and Academia in future professionals

Partner with universities and schools for the development Industry and and commercialization of E4 technologies Academia

Develop and commercialize educational platforms to ena- Industry, Government ble personalized and adaptive education and Academia

Develop a national policy with guidelines, objectives, and Industry, Government action plans for the modernization of education based on E4, and Academia which includes activities of training of people, educational management, and development of infrastructure

Develop legislation to ensure access to quality education Government and with the development of students' digital skills

Academia

Boost the use of E4 approaches and technologies at all le- Government and vels of education

Academia

Create centers that support public and private universities Government and to develop online learning platforms based on E4

Academia

Create technological infrastructure for E4 development in public education

Academia

Support financially the development of projects and re- Industry, Government search centers on $\mathrm{E} 4$ technologies and Academia

Create financing programs and partnerships with companies Industry, Government to capacitate future professionals in I4 technologies and Academia

Develop approaches for inserting E4 in teacher training

Government and

Academia

Use E4 technologies to include students with disabilities in Industry, Government

teaching platforms to train their employees, including on I4 technologies. In addition, companies can commercialize these courses and provide consulting services to other organizations that wish to use I4 technologies. The training can be offered through E4 
technologies such as RV, AR, and simulation. The benefits of using these technologies in training that offers worker safety risks or that are difficult to implement and reproduce are highlighted (Mian et al., 2020; Pedro et al., 2016).

In the Technology domain, the development and commercialization of educational platforms that use AI and DB tools to enable personalized and adaptive education are proposed. These technologies are useful to support teachers in the teaching-learning process through chatbots, virtual assistants, and by providing intelligent reports on students' academic performance. It is also proposed that companies partner with universities to research and develop effective hardware and software for E4 (Almohammadi et al., 2017; Huda et al., 2017).

The politics and initiatives proposed on the framework for Government are divided into the areas of Politics and Legislation, Education, and Economy. The proposals for Politics and Legislation are important to promote and encourage E4 from the creation of guidelines, objectives, and action plans for modernizing education. Access to computers, tablets, and interactive whiteboards in classrooms should be expanded. Also, legislation should ensure access to quality education and the development of digital skills of students to meet the demands for professionals trained to work at I4 (Benešová and Tupa, 2017).

In the Education domain, the use of E4 technologies is proposed to engage and motivate students in the teaching-learning process at all levels of education. It is also proposed to create centers that support the development of online teaching platforms with technologies such as DB, AI, CC for monitoring academic performance and sharing educational activities between teachers and students (Popenici and Kerr, 2017).

In the Economy domain, the allocation of financial resources to purchase computers, tablets and provide adequate Internet access is proposed for enabling the implementation of E4 at all levels of public education. In addition, it is necessary to encourage the creation of research centers at universities in partnership with companies and other countries for developing E4 technologies and the training of future professionals in I4 technologies (Wu et al., 2019a).

The initiatives proposed in the framework for Academia are divided into Education and Research domains. In Education, the development of methodologies for inserting E4 into the training of teachers is proposed, so that they can use it in teaching environments. It should be employed in courses and programs to provide greater inclusion of students in schools and the labor market, including students with disabilities from greater autonomy and better qualification. Besides, E4 should be implemented to increase student engagement in the subjects, especially STEM. Schools should include and offer blended learning in their courses and programs (Gil-Flores et al., 2017; Hsu et al., 2017; Smith et al., 2017).

In the Research domain, studies to take advantage of scientific opportunities and to overcome the E4 challenges identified in this work are suggested. It is also essential to propose an increasing number of solutions for integrating I4 technologies into education and to investigate the impacts of this integration, being a necessary mapping of skills and competencies necessary for professionals to work in I4 and to introduce them in the curricular grids (Akçayır and Akçayır, 2017; Gupta et al., 2015). 
Thus, the policies and initiatives of the proposed framework also must be conducted through constant interactions among Triple Helix agents. The government-academia interaction must promote and foster the development of E4 through the formation of research centers, the creation of policies for modernizing teaching, and teacher training to improve the quality of teaching. The government-industry interaction must provide funding and technological infrastructure for E4 and create partnerships to create training programs at I4. Finally, the industry-academia relationship must promote the continuous development of research and innovation, commercialization of technologies on the subject, and provision of the infrastructure necessary for E4 development in the teaching environments.

\section{Conclusion}

The fourth SDG established by the UN aims to ensure greater access to quality education, in consideration of education is crucial for developing society and must not be restricted to geographical or social barriers. The proposed E4 development framework aims to improve the teaching-learning process, making it more interactive, personalized, and accessible through the implementation of policies and initiatives for Triple Helix agents.

The main theoretical-scientific contribution of this work is the creation of a new block of knowledge that deepens and extends the existing literature, introducing good practices, challenges, and opportunities mapped in the technical-scientific scenario and the proposal of the framework containing a package of policies and initiatives. Thus, this work will support further studies on the theme based on the scientific challenges and opportunities for E4 development identified and the proposed framework.

The major applied contribution of this work is to enable the increase in access to quality education, modernization of the teaching-learning process, and improvement of the professionals' qualification demanded by I4. To that end, policies, and initiatives for E4 development were proposed to be adopted by Triple Helix agents, aiming to increase the engagement and motivation of students with the content taught through the integration of I4 technologies with teaching. In addition, the use of ICT and the Internet in teaching allows students from remote areas or those without financial resources for face-to-face courses to have access to effective online courses that enable adaptive, personalized, and student-centered learning.

Although the countries of technical and scientific prominence in the subject have been studied, the results of this article are limited to the experiences analyzed and the search criteria used. Obviously, if more countries and other databases were considered, other relevant policies and initiatives could be identified to support the authors in the elaboration of the proposed framework. Therefore, it is proposed that future studies use different search criteria to identify other countries with policies and initiatives that could be added to the framework for Triple Helix agents. Future studies could select countries considering the number of patents per capita in the technical scenario and the number of citations in the scientific scenario. In addition, exploratory studies and surveys could be conducted to identify the benefits and challenges of implementing E4 in developed and developing countries. 


\section{Acknowledgments}

This study was financed by the Coordenação de Aperfeiçoamento de Pessoal de Nível Superior - Brasil (CAPES) - Finance Code 001 and CNPq - Conselho Nacional de Desenvolvimento Científico e Tecnológico - National Council for Scientific and Technological Development (Ground Number 312894/2017-1).

\section{References}

Ab Rahman, R., Ahmad, S., Hashim, U.R. (2019). A study on gamification for higher education students' engagement towards education 4.0. In Lecture Notes in Networks and Systems, 67, 491-502.

Ahn, H.S., Choi, Y.-M. (2015). The development and application of the augmented reality based steam education program: Based on the inquiry learning model. International Journal of Applied Engineering Research, 10(10), 27243-27354.

Ahn, H.S., Choi, Y.-M. (2016). Utilizing augmented reality for creative writing educational contents and storyretelling. International Journal of Multimedia and Ubiquitous Engineering, 11(12), 71-82.

Akbulut, A., Catal, C., Yildı, B. (2018). On the effectiveness of virtual reality in the education of software engineering. Computer Applications in Engineering Education, 26(4), 918-927.

Akçayir, M., Akçayir, G., Pektaş, H.M., Ocak, M.A. (2016). Augmented reality in science laboratories: The effects of augmented reality on university students' laboratory skills and attitudes toward science laboratories. Computers in Human Behavior, 57, 334-342.

Akçayır, M., Akçayır, G. (2017). Advantages and challenges associated with augmented reality for education: A systematic review of the literature. Educational Research Review, 20, 1-11.

Alhalabi, W.S. (2016). Virtual reality systems enhance students' achievements in engineering education. Behaviour and Information Technology, 35(11), 919-925.

Almeida, F., Simoes, J. (2019). The Role of Serious Games, Gamification and Industry 4.0 Tools in the Education 4.0 Paradigm. Contemporary Educational Technology, 10(2).

Almohammadi, K., Hagras, H., Alghazzawi, D., Aldabbagh, G. (2017). A survey of artificial intelligence techniques employed for adaptive educational systems within e-learning platforms. Journal of Artificial Intelligence and Soft Computing Research, 7(1), 47-64.

Alvarenga, A.B.C.S., Espuny, M., Reis, J.S.M., Silva, F.D.O., Sampaio, N.A. de S., Nunhes, T.V., Barbosa, L.C.F.M., Santos, G., Oliveira, O.J. (2021). The Main Perspectives of The Quality of Life of Students In The Secondary Cycle: An Overview of The Opportunities, Challenges and Their Greatest Impact Elements. International Journal for Quality Research, 15(3).

Arpaci, I. (2017). Antecedents and consequences of cloud computing adoption in education to achieve knowledge management. Computers in Human Behavior, 70, 382-390.

Asamoah, M.K. (2021). ICT officials' opinion on deploying Open Source Learning Management System for teaching and learning in universities in a developing society. E-Learning and Digital Media, 18(1), 18-38.

Australian Government (2020). China's education modernisation plan towards 2035. https://internationaleducation.gov.au/International-network/china/PolicyUpdates-China/Pages/China's-education-modernisationplan-towards-2035-.aspx

Barber, S.R., Jain, S., Mooney, M.A., Almefty, K.K., Lawton, M.T., Son, Y.-J., Stevens, S.M. (2020). Combining Stereoscopic Video and Virtual Reality Simulation to Maximize Education in Lateral Skull Base Surgery. Otolaryngology - Head and Neck Surgery (United States), 162(6), 922-925.

Batista, A.F., Thiry, M., Gonçalves, R.Q., Fernandes, A. (2020). Using technologies as virtual environments for computer teaching: A systematic review. Informatics in Education, 19(2), 201-221.

Benešová, A., Tupa, J. (2017). Requirements for Education and Qualification of People in Industry 4.0. Procedia Manufacturing, 11(June), 2195-2202.

Bonfield, C.A., Salter, M., Longmuir, A., Benson, M., Adachi, C. (2020). Transformation or evolution?: Education 4.0, teaching and learning in the digital age. Higher Education Pedagogies, 5(1), 223-246.

Burns, T., Gottschalk, F. (Eds.) (2020). Education in the Digital Age. OECD.

Cai, S., Liu, C., Wang, T., Liu, E., Liang, J.C. (2020a). Effects of learning physics using Augmented Reality on students' self-efficacy and conceptions of learning. British Journal of Educational Technology, 0(0), 1-17.

Cai, S., Liu, E., Shen, Y., Liu, C., Li, S., Shen, Y. (2020b). Probability learning in mathematics using augmen- 
ted reality: impact on student's learning gains and attitudes. Interactive Learning Environments, 28(5), $560-573$.

CAMP (2014). Objectives. https : //camp. lcsr.jhu.edu/research/

Cao, W., Wang, Q., Sbeih, A., Shibly, F.H.A. (2020). Artificial intelligence based efficient smart learning framework for education platform. Inteligencia Artificial, 23(66), 112-123.

Chang, C.Y., Sung, H.Y., Guo, J.L., Chang, B.Y., Kuo, F.R. (2019). Effects of spherical video-based virtual reality on nursing students' learning performance in childbirth education training. Interactive Learning Environments, 0(0), 1-17.

Chang, K.E., Zhang, J., Huang, Y.S., Liu, T.C., Sung, Y.T. (2020a). Applying augmented reality in physical education on motor skills learning. Interactive Learning Environments, 28(6), 685-697.

Chang, S.C., Hwang, G.J. (2018). Impacts of an augmented reality-based flipped learning guiding approach on students' scientific project performance and perceptions. Computers and Education, 125(June), 226-239.

Chang, Y.S., Hu, K.J., Chiang, C.W., Lugmayr, A. (2020b). Applying mobile augmented reality (AR) to teach interior design students in layout plans: Evaluation of learning effectiveness based on the ARCS model of learning motivation theory. Sensors (Switzerland), 20(1).

Christ, R., Guevar, J., Poyade, M., Rea, P.M. (2018). Proof of concept of a workflow methodology for the creation of basic canine head anatomy veterinary education tool using augmented reality. PLoS ONE, 13(4), 1-16.

Chung, J.Y., Lee, S. (2019). Dropout early warning systems for high school students using machine learning. In Children and Youth Services Review, 96, 346-353.

Cope, B., Kalantzis, M. (2015). Interpreting Evidence-of-Learning: Educational research in the era of big data. Open Review of Educational Research, 2(1), 218-239.

Cronin, P., Ryan, F., Coughlan, M. (2008). Undertaking a literature review: a step-by-step approach. British Journal of Nursing (Mark Allen Publishing), 17(1), 38-43.

CSU (2019). Mosaic. https://biz.colostate.edu/resources/classroom-experience/mosaic

Dalenogare, L.S., Benitez, G.B., Ayala, N.F., Frank, A.G. (2018). The expected contribution of Industry 4.0 technologies for industrial performance. International Journal of Production Economics, 204(July), 383-394.

Daniel, B. (2015). Big Data and analytics in higher education: Opportunities and challenges. British Journal of Educational Technology, 46(5), 904-920.

Diao, P.H., Shih, N.J. (2019). Trends and research issues of augmented reality studies in architectural and civil engineering education - A review of academic journal publications. Applied Sciences (Switzerland), 9(9).

Duncum, P. (2018). Responding to Big Data in the Art Education Classroom: Affordances and Problematics. International Journal of Art and Design Education, 37(2), 325-332.

Fischer, C., Pardos, Z.A., Baker, R.S., Williams, J.J., Smyth, P., Yu, R., Slater, S., Baker, R., Warschauer, M. (2020). Mining Big Data in Education: Affordances and Challenges. Review of Research in Education, 44(1), 130-160.

Gachie, W. (2020). Higher education institutions, private sector and government collaboration for innovation within the framework of the Triple Helix Model. African Journal of Science, Technology, Innovation and Development, 12(2), 203-215.

Galan-Muros, V., Davey, T. (2019). The UBC ecosystem: putting together a comprehensive framework for university-business cooperation. Journal of Technology Transfer, 44(4), 1311-1346.

Ghavifekr, S., Rosdy, W.A.W. (2015). Teaching and learning with technology: Effectiveness of ICT integration in schools. International Journal of Research in Education and Science, 1(2), 175-191.

Ghobakhloo, M. (2018). The future of manufacturing industry: a strategic roadmap toward Industry 4.0. Journal of Manufacturing Technology Management, 29(6), 910-936.

Gil-Flores, J., Rodríguez-Santero, J., and Torres-Gordillo, J.J. (2017). Factors that explain the use of ICT in secondary-education classrooms: The role of teacher characteristics and school infrastructure. Computers in Human Behavior, 68, 441-449.

González-Martínez, J.A., Bote-Lorenzo, M.L., Gómez-Sánchez, E., Cano-Parra, R. (2015). Cloud computing and education: A state-of-the-art survey. Computers and Education, 80, 132-151.

Green, J., Green, T., Brown, A. (2017). Augmented Reality in the K-12 Classroom. TechTrends, 61(6), 603605.

Gupta, B., Goul, M., Dinter, B. (2015). Business intelligence and big data in higher education: Status of a multi-year model curriculum development effort for business school undergraduates, MS graduates, and MBAs. Communications of the Association for Information Systems, 36, 449-476.

Hämäläinen, R., Nissinen, K., Mannonen, J., Lämsä, J., Leino, K., Taajamo, M. (2021). Understanding teaching professionals' digital competence: What do PIAAC and TALIS reveal about technology-related skills, attitudes, and knowledge? Computers in Human Behavior, 117. 
Hariharasudan, A., Kot, S. (2018). A Scoping Review on Digital English and Education 4.0 for Industry 4.0. Social Sciences, 7(11), 227.

Haynes, D. (2019). Video Wall Brings Online Students to Class at Colorado State University - Samsung Business Insights. https://insights.samsung.com/2019/11/14/video-wall-brings-onlinestudents-to-class-at-colorado-state-university/

Hirsch, J. E. (2005). An index to quantify an individual's scientific research output. Proceedings of the $\mathrm{Na}$ tional Academy of Sciences of the United States of America, 102(46), 16569-16572.

Hofmann, E., Rüsch, M. (2017). Industry 4.0 and the current status as well as future prospects on logistics. Computers in Industry, 89, 23-34.

Hsiao, H.S., Chang, C.S., Lin, C.Y., Wang, Y.Z. (2016). Weather observers: a manipulative augmented reality system for weather simulations at home, in the classroom, and at museum. Interactive Learning Environments, 24(1), 205-223.

Hsu, T.C. (2019). Effects of gender and different augmented reality learning systems on English vocabulary learning of elementary school students. Universal Access in the Information Society, 18(2), 315-325.

Hsu, Y.S., Lin, Y.H., Yang, B. (2017). Impact of augmented reality lessons on students' STEM interest. Research and Practice in Technology Enhanced Learning, 12(1).

Hu, X., Han, Z.R. (2019). Effects of gesture-based match-to-sample instruction via virtual reality technology for Chinese students with autism spectrum disorders. International Journal of Developmental Disabilities, 65(5), 327-336.

Huang, C.L., Luo, Y.F., Yang, S.C., Lu, C.M., Chen, A.S. (2020). Influence of Students' Learning Style, Sense of Presence, and Cognitive Load on Learning Outcomes in an Immersive Virtual Reality Learning Environment. Journal of Educational Computing Research, 58(3), 596-615.

Huang, H.M., Liaw, S.S., Lai, C.M. (2016a). Exploring learner acceptance of the use of virtual reality in medical education: a case study of desktop and projection-based display systems. Interactive Learning Environments, 24(1), 3-19.

Huang, T.C., Chen, C.C., Chou, Y.W. (2016b). Animating eco-education: To see, feel, and discover in an augmented reality-based experiential learning environment. Computers and Education, 96, 72-82.

Huda, M., Maseleno, A., Shahrill, M., Jasmi, K.A., Mustari, I., Basiron, B. (2017). Exploring adaptive teaching competencies in big data era. International Journal of Emerging Technologies in Learning, 12(3), 68-83.

Hussenot, A. (2008). Between structuration and translation: An approach of ICT appropriation. Journal of Organizational Change Management, 21(3), 335-347.

Hwang, G.J., Wu, P.H., Chen, C.C., Tu, N.T. (2016). Effects of an augmented reality-based educational game on students' learning achievements and attitudes in real-world observations. Interactive Learning Environments, 24(8), 1895-1906.

IBM. (2020). P-TECH. https://www.ibm.org/initiatives/p-tech

Iserson, K.V. (2018). Ethics of Virtual Reality in Medical Education and Licensure. Cambridge Quarterly of Healthcare Ethics, 27(2), 326-332.

Jensen, L., Konradsen, F. (2018). A review of the use of virtual reality head-mounted displays in education and training. Education and Information Technologies, 23(4), 1515-1529.

Ji, Y., Han, Y. (2019). Monitoring indicators of the flipped classroom learning process based on data mining - taking the course of "virtual reality technology" as an example. International Journal of Emerging Technologies in Learning, 14(3), 166-176.

Jong, M.S.Y., Tsai, C.C., Xie, H., Kwan-Kit Wong, F. (2020). Integrating interactive learner-immersed videobased virtual reality into learning and teaching of physical geography. British Journal of Educational Technology, 51(6), 2063-2078.

Karakus, M., Ersozlu, A., Clark, A.C. (2019). Augmented reality research in education: A bibliometric study. Eurasia Journal of Mathematics, Science and Technology Education, 15(10).

KERIS (2020a). About. https://keris.or. kr/eng/cm/cntnts/cntntsView . do?mi=1172\&cntntsId=1321

KERIS (2020b). Project Areas. https://keris.or. kr/eng/cm/cntnts/cntntsView . do?mi=1179\&cntntsId=1326

Kimatu, J.N. (2015). Evolution of strategic interactions from the triple to quad helix innovation models for sustainable development in the era of globalization. Journal of Innovation and Entrepreneurship, 5(1), 0-6.

KOCW (2015). KOCW. http: //www. kocw. net/home/special/themeCourses.do\#subject/16

Koul, S., Nayar, B. (2021). The holistic learning educational ecosystem: A classroom 4.0 perspective. Higher Education Quarterly, 75(1), 98-112.

Le, Q.T., Pedro, A., Park, C.S. (2015). A Social Virtual Reality Based Construction Safety Education System for Experiential Learning. Journal of Intelligent and Robotic Systems: Theory and Applications, 79(3-4), 487-506. 
Lee, J., Bagheri, B., Kao, H.A. (2015). A Cyber-Physical Systems architecture for Industry 4.0-based manufacturing systems. Manufacturing Letters, 3, 18-23.

Li, H. (2017). Design of multimedia teaching platform for Chinese folk art performance based on virtual reality technology. International Journal of Emerging Technologies in Learning, 12(9), 28-40.

Li, L. (2020). Education supply chain in the era of Industry 4.0. Systems Research and Behavioral Science, 37(4), 579-592.

Li, X. (2016). Design and application of multimedia teaching video system for dance major based on cloud computing technology. International Journal of Emerging Technologies in Learning, 11(5), 22-26.

Liesa-Orús, M., Latorre-Cosculluela, C., Vázquez-Toledo, S., Sierra-Sánchez, V. (2020). The Technological Challenge Facing Higher Education Professors: Perceptions of ICT Tools for Developing 21st Century Skills. Sustainability, 12(13), 5339.

Lim, C., Lee, J., Choi, H. (2019). South Korea (pp. 87-100). Springer, Singapore.

Lim, C.P., Ra, S., Chin, B., Wang, T. (2020a). Information and communication technologies (ICT) for access to quality education in the global south: A case study of Sri Lanka. Education and Information Technologies, 25(4), 2447-2462.

Lim, C.P., Ra, S., Chin, B., Wang, T. (2020b). Leveraging information and communication technologies (ICT) to enhance education equity, quality, and efficiency: case studies of Bangladesh and Nepal. Educational Media International, 57(2), 87-111.

Lim, C.P., Yan, H., Xiong, X. (2015). Development of pre-service teachers' information and communication technology (ICT) in education competencies in a mainland Chinese university. Educational Media International, 52(1), 15-32.

Lincoln (2017). Lincoln Electric Education »Soluções de educação - Lincoln Electric Education. https://education.lincolnelectric.com/materials-equipment/education-solutions/

Lincoln Electric (2018). Virtual Reality Welding Simulators. https://education.lincolnelectric. com/products/welding-training-systems/virtual-reality-welding-simulators/

Liu, R., Wang, L., Lei, J., Wang, Q., Ren, Y. (2020). Effects of an immersive virtual reality-based classroom on students' learning performance in science lessons. British Journal of Educational Technology, 51(6), 2034-2049.

Lu, S.J., Liu, Y.C. (2015). Integrating augmented reality technology to enhance children's learning in marine education. Environmental Education Research, 21(4), 525-541.

Lucas, M., Bem-Haja, P., Siddiq, F., Moreira, A., Redecker, C. (2021). The relation between in-service teachers' digital competence and personal and contextual factors: What matters most? Computers and Education, 160, 104052.

Martín-Gutiérrez, J., Fabiani, P., Benesova, W., Meneses, M.D., Mora, C.E. (2015). Augmented reality to promote collaborative and autonomous learning in higher education. Computers in Human Behavior, 51, $752-761$.

McCarthy, T., Rosenblum, L.P., Johnson, B.G., Dittel, J., Kearns, D.M. (2016). An artificial intelligence tutor: A supplementary tool for teaching and practicing braille. Journal of Visual Impairment and Blindness, 110(5), 309-322.

McNeal, K.S., Ryker, K., Whitmeyer, S., Giorgis, S., Atkins, R., LaDue, N., Clark, C., Soltis, N., Pingel, T. (2020). A multi-institutional study of inquiry-based lab activities using the Augmented Reality Sandbox: impacts on undergraduate student learning. Journal of Geography in Higher Education, 44(1), 85-107.

Mian, S.H., Salah, B., Ameen, W., Moiduddin, K., Alkhalefah, H. (2020). Adapting universities for sustainability education in industry 4.0: Channel of challenges and opportunities. Sustainability (Switzerland), 12(15).

MoE of Taiwan (2012). Department of Information and Technology Education - Ministry of Education Republic of China (Taiwan). https : //english.moe.gov.tw/cpview-4-15160-AF176-1.html

MoE of Taiwan (2020). Digital Application Promotion Project in Remote Areas. https://itaiwan.moe.gov.tw/ english/index.php

Mongeon, P., Paul-Hus, A. (2016). The journal coverage of Web of Science and Scopus: a comparative analysis. Scientometrics, 106(1), 213-228.

Nikolopoulou, K., Akriotou, D., Gialamas, V. (2019). Early Reading Skills in English as a Foreign Language Via ICT in Greece: Early Childhood Student Teachers' Perceptions. Early Childhood Education Journal, 47, 597-606.

NSF (2020a). At a Glance. https : //www.nsf .gov/about/glance.jsp

NSF (2020b). Smart Advanced Manufacturing Education in the Silicon Valley. https://www.nsf.gov/awardsearch/showAward?AWD_ID=1902339\&HistoricalAwards=false

OECD (2018). Future of education and skills. Education2030. The future we want. Paris, France: OECD publications. www. oecd.org/education/2030/E2030\%20Position\%20Paper\%20(05.04.2018).pdf 
OECD (2020). PISA 2018 Results (Volume V): Vol. V. OECD. https://doi.org/10.1787/ca768d40-en

Okay Smart Education (2020). OK Learning Machine S4 Plus.

https://www.okayzhihui.com/studymachine.html

OKAY Smart Education (2017). OKAY Smart Education Releases World's First Intelligent Educational Device Ushers in the Era of Demand-Based Learning. Cision PR Newswire. https://www.prnewswire.com/ news-releases/the-7th-world-smart-education-summit-forum-worlds-first-intelligent-educational-device-ushers-in-the-era-of-demand-based-learning-300489022.html

Orlikowski, W.J. (2000). Using Technology and Constituting Structures: A Practice Lens for Studying Technology in Organizations. Organization Science, 11(4), 404-428.

P-TECH (2020). Open P-TECH . https://www.ptech.org/br/open-p-tech/

Paquette, L., Baker, R.S. (2019). Comparing machine learning to knowledge engineering for student behavior modeling: a case study in gaming the system. Interactive Learning Environments, 27(5-6), 585-597.

Pedro, A., Le, Q.T., Park, C.S. (2016). Framework for Integrating Safety into Construction Methods Education through Interactive Virtual Reality. Journal of Professional Issues in Engineering Education and Practice, 142(2).

Pereira, A.C., Romero, F. (2017). A review of the meanings and the implications of the Industry 4.0 concept. Procedia Manufacturing, 13, 1206-1214.

Pham, H.C., Dao, N.N., Pedro, A., Le, Q.T., Hussain, R., Cho, S., Park, C.S. (2018). Virtual field trip for mobile construction safety education using 360-degree panoramic virtual reality. International Journal of Engineering Education, 34(4), 1174-1191.

Popenici, S.A.D., Kerr, S. (2017). Exploring the impact of artificial intelligence on teaching and learning in higher education. Research and Practice in Technology Enhanced Learning, 12(1).

Qasem, Y.A.M., Abdullah, R., Jusoh, Y.Y., Atan, R., Asadi, S. (2019). Cloud Computing Adoption in Higher Education Institutions: A Systematic Review. IEEE Access, 7, 63722-63744.

Razorenov, Y.I., Vodenko, K.V. (2020). Innovative development of the national university system in Russia: trends and key elements. International Journal of Sociology and Social Policy, 41(1-2), 253-262.

Redecker, C. (2017). European framework for the digital competence of educators: DigCompEdu. Joint Research Centre (JRC) Science for Policy Report, 95.

Reis, J.S.M., Ferreira Costa, A.C., Espuny, M., Batista, W.J., Francisco, F.E., Gonçalves, G.S., Tasinaffo, P.M., Vieira Dias, L.A., da Cunha, A.M., Oliveira, O.J. (2020). Education 4.0: Gaps Research Between School Formation and Technological Development. In Advances in Intelligent Systems and Computing (Vol. 1134, pp. 415-420). Springer.

Reis, T.L., Mathias, M.A.S., Oliveira, O.J. (2017). Maturity models : identifying the state-of-the-art and the scientific gaps from a bibliometric study. Scientometrics, 110(2), 643-672.

Reyes, J.A. (2015). The skinny on big data in education: Learning analytics simplified. TechTrends, 59(2), 75-80.

Rojko, A. (2017). Industry 4.0 concept: Background and overview. International Journal of Interactive Mobile Technologies, 11(5), 77-90.

Sabi, H.M., Uzoka, F.M.E., Langmia, K., Njeh, F.N. (2016). Conceptualizing a model for adoption of cloud computing in education. International Journal of Information Management, 36(2), 183-191.

Samsung (2013). Technology in Education. https://www.samsung.com/us/business/solutions/industries/education/

Samsung (2020a). Cultivate key human resources who will lead the 4th Industrial Revolution. Samsung Innovation Campus. http://csr.samsung.com/en/programViewSic.do

Samsung (2020b). Education that can enable anyone to do anything. Samsung Smart School. http: //csr. samsung.com/en/programViewSs.do

Samsung (2020c). Just one week can start a long, meaningful relationship and change. Samsung OneWeek. http: //csr. samsung. com/en/programViewOneweek. do

Scherer, R., Siddiq, F., Teo, T. (2015). Becoming more specific: Measuring and modeling teachers' perceived usefulness of ICT in the context of teaching and learning. Computers and Education, 88, 202-214.

Schneider, D., Chambers, A., Mather, N., Bauschatz, R., Bauer, M., Doan, L. (2015). The effects of an ICTbased reading intervention on students' achievement in grade two. Reading Psychology, 37(5), 798-831.

Shackelford, L., David Huang, W., Craig, A., Merrill, C., Chen, D. (2019). Relationships between motivational support and game features in a game-based virtual reality learning environment for teaching introductory archaeology. Educational Media International, 56(3), 183-200.

Shengli, X., Xingran, Z., Weihua, Y., Ya, C., Wenping, W., Hong, Y. (2019). Electric power teaching switching operation virtual reality teaching cabinet (Patent No. CN201922058970U).

Shi, Y., Yang, H.H., Yang, Z., Wu, D. (2014). Trends of cloud computing in education. Lecture Notes in Com- 
puter Science (Including Subseries Lecture Notes in Artificial Intelligence and Lecture Notes in Bioinformatics), 8595 LNCS, 116-128.

Shiau, W.L., Chau, P.Y.K. (2016). Understanding behavioral intention to use a cloud computing classroom: A multiple model comparison approach. Information and Management, 53(3), 355-365.

Shuo, Z. (2019). 2 plans detail China's goals for education. The State Council The Peopleo's Republic of China.

http://english.www.gov.cn/policies/policy_watch/2019/02/25/content_281476537597482.htm

Skryabin, M., Zhang, J., Liu, L., Zhang, D. (2015). How the ICT development level and usage influence student achievement in reading, mathematics, and science. Computers and Education, 85, 49-58.

Smith, C.C., Cihak, D.F., Kim, B., McMahon, D.D., Wright, R. (2017). Examining Augmented Reality to Improve Navigation Skills in Postsecondary Students With Intellectual Disability. Journal of Special Education Technology, 32, 3-11.

Soltis, N.A., McNeal, K.S., Atkins, R.M., Maudlin, L.C. (2020). A novel approach to measuring student engagement while using an augmented reality sandbox. Journal of Geography in Higher Education, 44(4), $512-531$.

Southgate, E., Smith, S.P., Cividino, C., Saxby, S., Kilham, J., Eather, G., Scevak, J., Summerville, D., Buchanan, R., Bergin, C. (2019). Embedding immersive virtual reality in classrooms: Ethical, organisational and educational lessons in bridging research and practice. International Journal of Child-Computer Interaction, 19, 19-29.

Squirrel AI Learning (2017). 1st AI-powered adaptive education provider in China. http://squirrelai.com/

Squirrel AI Learning (2020). Product. http://squirrelai.com/product/ials

State Grid Corporation (2017). Corporate Profile. http://www.sgcc.com.cn/html/sgcc_main_en/col2017112307/column_2017112307_1.shtml

Takala, T.M., Malmi, L., Pugliese, R., Takala, T. (2016). Empowering students to create better virtual reality applications: A longitudinal study of a VR capstone course. Informatics in Education, 15(2), 287-317.

Tashkandi, A.N., Al-Jabri, I.M. (2015). Cloud computing adoption by higher education institutions in Saudi Arabia: An exploratory study. Cluster Computing, 18(4), 1527-1537.

Terzopoulos, G., Satratzemi, M. (2020). Voice Assistants and Smart Speakers in Everyday Life and in Education. Informatics in Education, 19(3), 473-490.

Total Soft Bank (2008). Overview. http://www.tsb.co.kr/en/sub05_01.php

Total Soft Bank (2018). Simulator. http://www.tsb.co.kr/en/sub01_04.php

U.S. Department of Education (2019). TITLE IV-21st CENTURY SCHOOLS - Every Student Succeeds Act (ESSA). https://www2.ed.gov/policy/elsec/leg/essa/legislation/title-iv.html

UN (2020). Sustainable Development Goals - Quality Education. https://www.un.org/sustainabledevelopment/education/

UNESCO (2017). ICT in education. https : //en . unesco.org/themes/ict-education

UNESCO (2018). Quick Guide to Education Indicators for SDG 4.

University of Tennessee (2012). Theory \& Practice in Teacher Education. https://tpte.utk.edu/people/david-f-cihak-phd/

Valtonen, T., Kukkonen, J., Kontkanen, S., Sormunen, K., Dillon, P., Sointu, E. (2015). The impact of authentic learning experiences with ICT on pre-service teachers' intentions to use ICT for teaching and learning. Computers and Education, 81, 49-58.

Vincent, C.L., Singh, V., Chakraborty, K., Gopalakrishnan, A. (2017). Patent data mining in fisheries sector: An analysis using Questel-Orbit and Espacenet. World Patent Information, 51, 22-30.

Wang, S., Wan, J., Li, D., Zhang, C. (2016). Implementing Smart Factory of Industrie 4.0: An Outlook. International Journal of Distributed Sensor Networks, 2016.

Washington State University (2016). Assistive Technology Research \& Development Lab. https://labs.wsu.edu/assistivetech/

Washington State University (2020). Don McMahon - College of Education. https://education.wsu.edu/don-mcmahon/

WEF (2020). Schools of the future: Defining new models of education for the fourth industrial revolution. World Economic Forum Reports 2020, January, 1-33. www . wef orum. org

Wei, X., Weng, D., Liu, Y., Wang, Y. (2015). Teaching based on augmented reality for a technical creative design course. Computers and Education, 81, 221-234.

Wu, D., Li, C.C., Zhou, W.T., Tsai, C.C., Lu, C. (2019a). Relationship between ICT supporting conditions and ICT application in Chinese urban and rural basic education. Asia Pacific Education Review, 20(1), $147-157$.

Wu, J., Guo, R., Wang, Z., Zeng, R. (2019b). Integrating spherical video-based virtual reality into elementary 
school students' scientific inquiry instruction: effects on their problem-solving performance. Interactive Learning Environments, 0(0), 1-14.

$\mathrm{Xu}, \mathrm{L} . \mathrm{Da}, \mathrm{Xu}, \mathrm{E} . \mathrm{L} ., \mathrm{Li}, \mathrm{L}$. (2018). Industry 4.0: State of the art and future trends. International Journal of Production Research, 56(8), 2941-2962.

Xuecheng, L. (2019). Portable on-line education terminal of artificial intelligence (Patent No. CN109887355). GANSU PUGONGYING INFORMATION TECHNOLOGY.

Yan, Z., Xiaojing, G., Yongsheng, H., Liping, G., Yanjie, S., Zhenyu, Y., Weimin, L., Zhangao, L., Chenlu, L., Yalin, L., Rui, C., Xiaoyi, H., Lili, L., Chaole, W., Fan, C. (2016). VR (virtual reality) device for simulation teaching of power transmission and distribution major (Patent No. CN106448280A).

Yang, S.J.H., Huang, C.S.J. (2016). Taiwan digital learning initiative and big data analytics in education cloud. Proceedings - 2016 5th IIAI International Congress on Advanced Applied Informatics, IIAI-AAI 2016, 366-370.

Yilmaz, R.M. (2016). Educational magic toys developed with augmented reality technology for early childhood education. Computers in Human Behavior, 54, 240-248.

Yusuf, B., Walters, L.M., Sailin, S.N. (2020). Restructuring Educational Institutions for Growth in the Fourth Industrial Revolution (4IR): A Systematic Review. International Journal of Emerging Technologies in Learning (IJET), 15(03), 93-109.

Zhang, D., Liu, L. (2016). How does ICT use influence students' achievements in math and science over time? Evidence from PISA 2000 to 2012. Eurasia Journal of Mathematics, Science and Technology Education, 12(9), 2431-2449.

Zhang, W., Zhu, Y. (2017). A new E-learning model based on elastic cloud computing for distance education. Eurasia Journal of Mathematics, Science and Technology Education, 13(12), 8393-8403.

A.C.F. Costa is a master's student in Production Engineering at Sao Paulo State University (UNESP) - Guaratinguetá, Campus and graduated from the Fluminense Federal University in 2018. Currently, she studies Industry 4.0 technologies for the improvement of the teaching-learning process.

V.H.M. Santos is a graduate student in Mechanical Production Engineering from São Paulo State University (UNESP) - Guaratinguetá Campus since 2016. During his graduation, he participated in diverse student organizations as Junior Company, Academic Center, and Study Nucleus. He was a scholarship holder is researching operations research in 2018 by the Foundation for the Development of Science and Technology (FDCT/UNESP). In 2019, he was a scholarship holder of the Foundation for Research Support of the State of São Paulo (FAPESP) studying Cleaner Production, Risk Management, and Education 4.0

O.J. de Oliveira is a Civil Eng., MS, and PhD in Engineering. He is an Associate Professor at São Paulo State University (UNESP). He is the coordinator of the Production Engineering Post Graduation Programme at UNESP, Guaratinguetá campus. His line of research encompasses Quality and Environment Management, mainly ISO 9001, ISO 14001, and Lean Six Sigma. 


\section{APPENDIX A}

\section{The most cited articles from 2015 to 2020}

\begin{tabular}{|c|c|}
\hline Article Name & Authors \\
\hline $\begin{array}{l}\text { Advantages and challenges associated with augmented } \\
\text { reality for education: A systematic review of the literature }\end{array}$ & $\begin{array}{l}\text { Akçayır and } \\
\text { Akçayır }\end{array}$ \\
\hline $\begin{array}{l}\text { Big Data and analytics in higher education: Opportunities } \\
\text { and challenges }\end{array}$ & Daniel \\
\hline Cloud computing and education: A state-of-the-art survey & $\begin{array}{l}\text { González- } \\
\text { Martínez et al. }\end{array}$ \\
\hline $\begin{array}{l}\text { Augmented reality to promote collaborative and autono- } \\
\text { mous learning in higher education }\end{array}$ & $\begin{array}{l}\text { Martín- } \\
\text { Gutiérrez et al. }\end{array}$ \\
\hline $\begin{array}{l}\text { Augmented reality in science laboratories: The effects of } \\
\text { augmented reality on university students' laboratory skills } \\
\text { and attitudes toward science laboratories }\end{array}$ & Akç \\
\hline $\begin{array}{l}\text { Conceptualizing a model for adoption of cloud computing } \\
\text { in education }\end{array}$ & Sabi et al. \\
\hline
\end{tabular}

Animating eco-education: To see, feel, and discover in an Huang et al. augmented reality-based experiential learning environment

Educational magic toys developed with augmented reality Yilmaz technology for early childhood education

Understanding behavioral intention to use a cloud comput- Shiau and ing classroom: A multiple model comparison approach

Chau

Year Journal

Teaching based on augmented reality for a technical crea- Wei et al. tive design course

Requirements for Education and Qualification of People in Benešová and Industry 4.0 Tupa

Factors that explain the use of ICT in secondary-education Gil-Flores classrooms: The role of teacher characteristics and school et al. infrastructure

Teaching and learning with technology: Effectiveness of Ghavifekr and ICT integration in schools

Rosdy

Antecedents and consequences of cloud computing adoption Arpaci in education to achieve knowledge management

Effects of an augmented reality-based educational game on Hwang et al. students' learning achievements and attitudes in real-world observations

The impact of authentic learning experiences with ICT on Valtonen et al. pre-service teachers' intentions to use ICT for teaching and learning

Exploring adaptive teaching competencies in big data era Huda et al.

Integrating augmented reality technology to enhance Lu and Liu children's learning in marine education
2017 Educational Research Review

2015 British Journal of Educational Technology

2015 Computers and Education

2015 Computers in Human Behavior

2016 Computers in Human Behavior

2016 International Journal of Information Management

2016 Computers and Education

2016 Computers in Human Behavior

2016 Information and Management

2015 Computers and Education

2017 Procedia Manufacturing

2017 Computers in Human Behavior

2015 International Journal of Research in Education and Science

2017 Computers in Human Behavior

2016 Interactive Learning Environments

2015 Computers and Education

2017 International Journal of Emerging Technologies in Learning

2015 Environmental Education Research 
Table continued from previous page

\begin{tabular}{llll}
\hline Article Name & Authors & Year & Journal \\
\hline $\begin{array}{l}\text { A review of the use of virtual reality head-mounted displays } \\
\text { in education and training }\end{array}$ & $\begin{array}{l}\text { Jensen and } \\
\text { Konradsen }\end{array}$ & $2018 \begin{array}{l}\text { Education and Informa- } \\
\text { tion Technologies }\end{array}$ \\
$\begin{array}{l}\text { A Social Virtual Reality Based Construction Safety Educa- } \\
\text { tion System for Experiential Learning }\end{array}$ & $2015 \begin{array}{l}\text { Journal of Intelligent and } \\
\text { Robotic Systems: Theory }\end{array}$ \\
& & $\begin{array}{l}\text { and Applications } \\
\text { and }\end{array}$
\end{tabular}

How the ICT development level and usage influence student Skryabin et al. 2015 Computers and Education achievement in reading, mathematics, and science

Exploring learner acceptance of the use of virtual reality in Huang et al. medical education: a case study of desktop and projection-

2016 Interactive Learning Enbased display systems vironments

Becoming more specific: Measuring and modeling teachers' Scherer et al. perceived usefulness of ICT in the context of teaching and learning

Impacts of an augmented reality-based flipped learning Chang and guiding approach on students'scientific project performance Hwang and perceptions

Virtual reality systems enhance students' achievements in Alhalabi engineering education

Exploring the impact of artificial intelligence on teaching Popenici and and learning in higher education

Kerr

Business intelligence and big data in higher education: Gupta et al. Status of a multi-year model curriculum development effort for business school undergraduates, MS graduates, and MBAs

The skinny on big data in education: Learning analytics Reyes simplified

A survey of artificial intelligence techniques employed for Almohammadi adaptive educational systems within e-learning platforms et al.

Cloud computing adoption by higher education institutions Tashkandi and in Saudi Arabia: An exploratory study
Al-Jabri
2015 Computers and Education

2018 Computers and Education

2016 Behaviour and Information Technology

2017 Research and Practice in Technology Enhanced Learning

2015 Communications of the Association for Information Systems

2015 TechTrends

2017 Journal of Artificial Intelligence and Soft Computing Research

2015 Cluster Computing 